Review Article

\title{
A Systematic Review on Indoor Environmental Quality in Naturally Ventilated School Classrooms: A Way Forward
}

\author{
Nishant Raj Kapoor $\mathbb{D}^{1,2}$ Ashok Kumar $\mathbb{D}^{1,2}$ Chandan Swaroop Meena $\mathbb{D}^{1,2}$ \\ Anuj Kumar $\mathbb{D}^{1,2}$ Tabish Alam $\mathbb{D}^{1,2}$ Nagesh Babu Balam $\mathbb{D}^{1,2}$ and Aritra Ghosh $\mathbb{D}^{3}$ \\ ${ }^{1}$ CSIR-Central Building Research Institute, Roorkee 247667, India \\ ${ }^{2}$ Academy of Scientific and Innovative Research (AcSIR), Ghaziabad 201002, India \\ ${ }^{3}$ University of Exeter, Penryn, TR10 9FE, Cornwall, UK \\ Correspondence should be addressed to Nishant Raj Kapoor; nishant@cbri.res.in, Chandan Swaroop Meena; \\ chandanswaroop2008@gmail.com, and Aritra Ghosh; a.ghosh@exeter.ac.uk
}

Received 28 August 2020; Revised 19 January 2021; Accepted 27 January 2021; Published 18 February 2021

Academic Editor: Andreas Lampropoulos

Copyright (C) 2021 Nishant Raj Kapoor et al. This is an open access article distributed under the Creative Commons Attribution License, which permits unrestricted use, distribution, and reproduction in any medium, provided the original work is properly cited.

\begin{abstract}
This review presents the existing state-of-the-art practices of indoor environmental quality (IEQ) in naturally ventilated school buildings and is mainly focused on the components of IEQ like thermal comfort, indoor air quality with ventilation, and visual and acoustic comfort. This article also discusses the impacts of COVID-19 on naturally ventilated school buildings, highlighting the obviousness of dynamic applications that concentrate on reducing COVID-19 effects in naturally ventilated school buildings. The importance of the concerned issues and factors are discussed in detail for future research direction. This review is a step toward the development of the IEQ standard for naturally ventilated school buildings.
\end{abstract}

\section{Introduction}

1.1. Overview. In developing countries, people are likely to spend more of their time indoors. People spent approx $90 \%$ of their total time indoors [1]. People spend about $65 \%$ or more of their time at their homes, depending on various factors such as age, gender, job type, indoor comfort, and indoor environmental quality [2]. Based on these findings, the indoor environmental conditions are important for learning, health, wellbeing, general working patterns, and economic growth. As per the National Building Code of India Part IV-2016 [3], buildings are classified into nine types, namely, residential, educational, institutional, assembly, business, mercantile, industrial, store, and hazardous. Educational buildings like schools, universities, and colleges are some of the most important buildings where one-fifth of the world population spends more than $30 \%$ of their time $[4,5]$. The quality of learning and performing various tasks are directly related to the indoor environmental quality (IEQ) of any building. Good IEQ in educational buildings enhances the health and the learning capabilities of students and increases productivity and efficiency [6]. However, most of the IEQ studies done in India and around the globe focus on residential and commebuildings [7], whereas research studies on school buildings are scarce in India. The overall indoor environmental quality of a regularly occupied space in the long term is determined by ergonomics, indoor thermal comfort, electromagnetic radiation level, quality of indoor air, acoustic comfort, hygiene, visual comfort, furniture-space layout, micro/macroorganisms, and aesthetics $[8,9]$. According to the National Institute for Occupational Safety and Health (NIOSH) 2013 [10], IEQ is defined as "the quality of a building's environment concerning the health and wellbeing of its occupants and includes aspects of design, analysis, and operation that lead to energy-efficient, healthy, and comfortable buildings."

There is a direct relationship between the building's indoor conditions and an occupant's health. Factors such as poor maintenance, bad IEQ, and building age will lead to 
worsening of the building's condition and have a negative impact on the occupant's health. Educational buildings with poor IEQ can reduce the concentration and performance of occupants. Fromme et al. [11] discussed the positive effects of good IEQ on the teaching and learning process in students and teachers. IEQ affects occupant's confidence, performance, absenteeism, learning outcome, and job satisfaction [12-16]. Carlopio and de Dear et al. [17, 18] explained how poor job satisfaction can lead occupants to leave a job. Building IEQ interacts dynamically with its user and affects them physiologically and psychologically [19-21]. The unhealthy buildings, in the long run, are very harmful to their users and can cause illness and various types of disease. Clinically, it is defined as building-related illness (BRI) and sick building syndrome (SBS) [22]. BRI symptoms can be clinically defined and have identifiable causes, whereas symptoms of SBS can be seen in occupants for a short duration, but the cause of symptoms is not known. Symptoms associated with BRI are chest tightness, fever, chills, cough, and muscle ache, and symptoms of SBS are eye, throat, or nose irritation; headaches; dry or itchy skin; dry cough; nausea and dizziness; fatigue; odors' sensitivity; and difficulty in concentration. Most of the SBS complaints report relief after leaving the building, while BRI complaints require a long duration for recovery. The causes of SBS are inadequate ventilation, outdoor-indoor chemical and biological contaminants, etc. All the causes of BRI and SBS are directly related to the IEQ of a building; thus, it becomes more important to study the IEQ in school buildings [22-25]. Catalina and Ioardache [26] focused on enhancing the demand for IEQ studies in school buildings. School buildings include preschool (kindergarten), primary school (elementary school), upper primary (middle) school, secondary school, and senior secondary school. Different schools have different age groups of students, which is presented in Figure 1. The National Education Policy 2020 [27] has modified the Indian educational structure recently, which is also presented in Figure 1. In India, approximately 1.4 million schools are owned and run by the government [28]. The majority of Indian school buildings are naturally ventilated $(\mathrm{NV})$ and mixed-mode ventilated schools are minimum.

1.2. Objectives of the Study. Indoor environmental quality (IEQ) inside a building is the key element to make a building suitable for human habitation, learning, and working. The IEQ in naturally ventilated school buildings is an important component because students in the age group of 3-18 years spend an ample amount of time (4-7 hours) in schools. Based on the prior state of the art, the research area of $\mathrm{NV}$ school buildings is in the premature stage and needs further research on IEQ. And more so, IEQ is a major challenge in the COVID-19 scenario for sustainable indoor environments in naturally ventilated school buildings. It is affecting the performance and health of the inhabitants. The IEQ study is a necessary component in the area of school building research for the wellbeing and better performance of the students.
Therefore, the main aim of this article is to identify the necessity of IEQ in NV school buildings during the COVID19 scenario for maintaining the IEQ and also to suggest the future research direction. The objectives are as follows: (i) to understand the existing knowledge of IEQ and comfort in NV school buildings and (ii) to identify research and data gaps in the developed knowledge and propose future research related to IEQ in NV school classrooms.

The paper contains a general introduction of IEQ and school buildings in the first section. The second section explains the review methodology adopted. The IEQ in NV school buildings is discussed in detail with all its components in the third and fourth sections. The fifth section describes COVID-19 impacts on NV schools. The sixth section contains a combined discussion and conclusion with some key ideas for future work focusing on providing better IEQ in NV school buildings.

\section{Methodology}

A four-stage procedure is adopted for the creation of this review. The four stages are presented in Figure 2.

For identification, a preliminary survey for an up-to-date published review article is performed. According to the preliminary survey, an outcome research criterion is fixed and important keywords for the NV school buildings are identified. These are: IEQ, thermal comfort, indoor air quality, teacher performance and productivity, lighting and illumination, acoustics in schools, sick building syndrome, building-related illness, ventilation, and integration of daylight. For the literature review, Web of Science, IEEE Access, Research Gate, Academia, and Google Scholar are used. Standards and reports are collected from official websites. In the classification stage, preclassification is done based on abstracts. Irrelevant articles are discarded from the review. All the included articles are read full and articles falling out of criteria are removed. After detailed analyses of the articles reviewed, as shown in Figure 3, all the ideas generated through the understanding of existing knowledge are organized and linked together to form a systematic review, which is then followed by a conclusion and future directions.

2.1. Indoor Environmental Quality. Healthy and comfortable life is the topmost priority of every building user. Corresponding to health and wellbeing, the quality of a built environment for its occupant inside a building is referred to as indoor environmental quality. IEQ involves a series of complex trends that merge Indoor Air Quality (IAQ), noise disturbance, occupant density, indoor lighting, daylighting, ventilation, room temperature, cleanliness, indoor humidity, and ergonomics. All these factors add up and we call it IEQ as a whole; it simply defines the importance of building engineering in molding the health of building occupants living or working inside. The main IEQ components are thermal comfort (TC), visual comfort (VC), indoor air quality (IAQ) (including ventilation), and acoustic comfort 


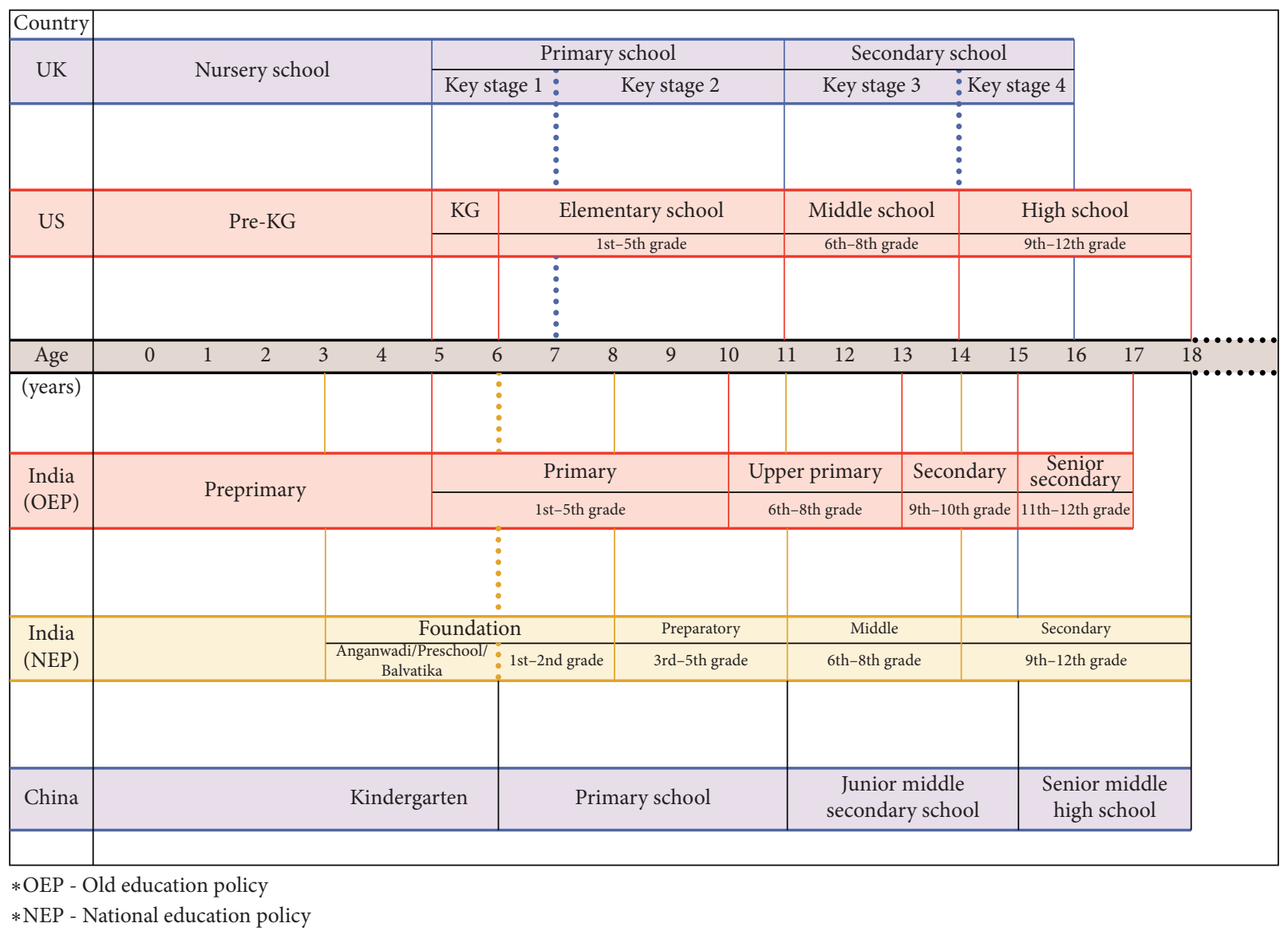

Figure 1: Structure of the educational system of different countries.

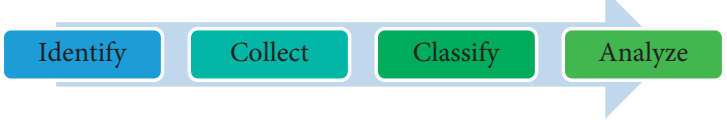

Figure 2: Four stages for review.

(AcC). There are no IEQ codes specifically for schools but some related codes are included in Table 1.

In NV schools, productivity, concentration, and efficiency are increased due to good IEQ conditions, and health impacts are the least on students and teachers. Students and teachers spend approximately half of their total indoor time in school buildings majorly in classrooms. In the majority of cases, there is a shortage of funds for providing a better indoor environment in schools globally. NV schools of urban areas are more prone to poor IAQ and excessive noise conditions. Most of the schools are situated near markets or surrounded by busy surroundings in urban areas. The balance between low noise and good air circulation in the classroom through an open window is difficult to achieve in a noisy and polluted urban environment. Schneider [39] studied the relationship between relative humidity in school buildings and student absenteeism patterns. The study indicated that when the humidity is more, more students feel sick and fungal growth is also increased.
Hanushek and Rivkin [40] explained that teachers work for less salary and even perform better if the IEQ is good inside classrooms. Becker et al. [41] and Fisk et al. [42] explained that good IEQ can lead toward large economic benefits, reduced health issues, and annual productivity gains. Studies show that poor IEQ has various long- and short-term health impacts on building occupants [43]. Poor IAQ can lead to severe health issues such as allergies, headaches, nausea, dizziness, asthma, and other respiratory and cardiovascular diseases $[44,45]$. In addition, conditions such as bad thermal comfort $\left(<16^{\circ} \mathrm{C}\right.$ and $\left.>33.7^{\circ} \mathrm{C}\right)[46]$, poor acoustics (background noise $>35 \mathrm{db}$ and reverberation time $>0.7$ seconds) [38], and improper lighting (inadequate, i.e., $<200$ lux or excessively bright, i.e., $>500$ lux) [30] could increase the stress level in an occupant's body and increase health risks like sleep disorder, concentration loss, amnesia, digestive problems, anger, etc. Studies considered in this review are depicted in Table 2.

An indoor environment with good IEQ improves the occupant's mood, which affects the comfort perception of the occupant. Productivity increases with good health and improves the mood of the worker inside the building, which is well supported by research [47]. Kielb et al. [48] researched New York public school teachers' satisfaction with indoor environmental features of the classroom. They found that inadequate ventilation and poor building conditions are directly associated with various ill-health 


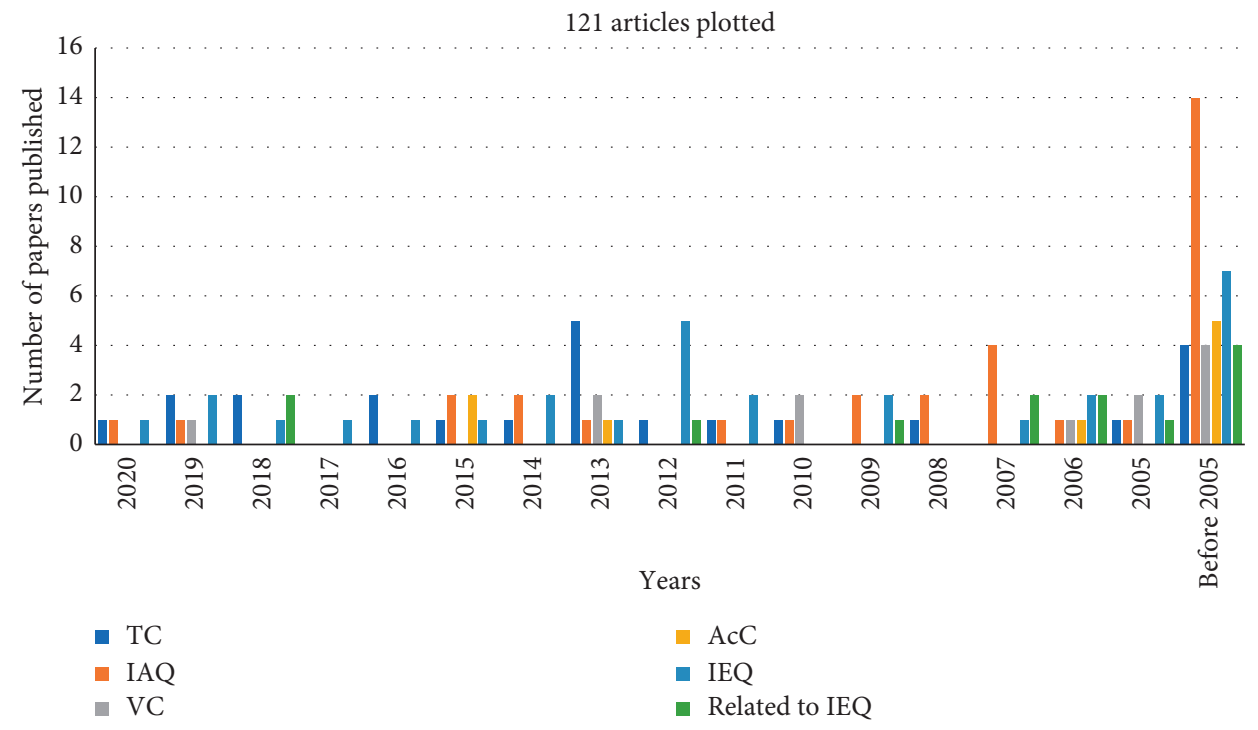

FIGURE 3: Number of papers published over the years on classroom IEQ parameters.

TABLE 1: Indian and international codes on IEQ parameters.

\begin{tabular}{|c|c|c|c|c|}
\hline \multirow[b]{2}{*}{ Codes } & \multicolumn{4}{|c|}{ Parameters } \\
\hline & Thermal comfort & Visual comfort & $\begin{array}{l}\text { Indoor air quality } \\
\text { and ventilation }\end{array}$ & Acoustic comfort \\
\hline Indian national codes & $\begin{array}{l}\text { SP-41 [29]NBC, } 2016 \text { [30], } \\
\text { ISHRAE 10001:2019 [31] }\end{array}$ & $\begin{array}{l}\text { SP-41 [29]NBC, } 2016 \text { [30], } \\
\text { ISHRAE } 10001: 2019 \text { [31] }\end{array}$ & $\begin{array}{c}\text { ISHRAE } \\
10001: 2019[31]\end{array}$ & $\begin{array}{c}\text { NBC, } 2016 \text { [30] ISHRAE } \\
10001: 2019 \text { [31] }\end{array}$ \\
\hline International codes & $\begin{array}{c}\text { ASHRAE } 55 \text { [32], ISO } 7730 \text { [33], } \\
\text { EN 16798 [34] }\end{array}$ & EN 12665 [35], ISO 8995 [36] & ASHRAE 62.1 [37] & ANSI S12.60 [38] \\
\hline
\end{tabular}

TABLE 2: IEQ parameters study spread over the publication years.

\begin{tabular}{|c|c|c|c|c|c|c|c|}
\hline Publication year & $\mathrm{TC}$ & IAQ & $\mathrm{VC}$ & $\mathrm{AcC}$ & IEQ & Related to IEQ & Cited papers \\
\hline 2020 & 1 & 1 & - & - & 1 & - & 3 \\
\hline 2019 & 2 & 1 & 1 & - & 2 & - & 6 \\
\hline 2018 & 2 & - & - & - & 1 & 2 & 5 \\
\hline 2017 & - & - & - & - & 1 & - & 1 \\
\hline 2016 & 2 & - & - & - & 1 & - & 3 \\
\hline 2015 & 1 & 2 & - & 2 & 1 & - & 6 \\
\hline 2014 & 1 & 2 & - & - & 2 & - & 5 \\
\hline 2013 & 5 & 1 & 2 & 1 & 1 & - & 10 \\
\hline 2012 & 1 & - & - & - & 5 & 1 & 6 \\
\hline 2011 & 1 & 1 & - & - & 2 & - & 4 \\
\hline 2010 & 1 & 1 & 2 & - & - & - & 4 \\
\hline 2009 & - & 2 & - & - & 2 & 1 & 5 \\
\hline 2008 & 1 & 2 & - & - & - & - & 3 \\
\hline 2007 & - & 4 & - & - & 1 & 2 & 7 \\
\hline 2006 & - & 1 & 1 & 1 & 2 & 2 & 7 \\
\hline 2005 & 1 & 1 & 2 & - & 2 & 1 & 7 \\
\hline Before 2005 & 4 & 14 & 4 & 5 & 7 & 4 & 39 \\
\hline Total & 23 & 33 & 12 & 9 & 31 & 13 & 121 \\
\hline
\end{tabular}

symptoms. Poor IEQ enhanced the probability of taking sick leaves due to regular ill-health [49-51]. Significant absenteeism affects student's results, which, in turn, affects them psychologically. Kumar et al. [52] discussed various sensing technologies to enhance the IEQ in buildings. By using intelligent systems, school buildings can easily increase the
IEQ. In the joint India-UK project, "Learn-BPE” [53], researchers have performed an occupants' survey to assess the indoor quality in ten buildings including one educational building. The researchers pointed out that IEQ must be given prime importance while designing buildings or retrofitting old ones. There are global opportunities for conducting IEQ 
research in school buildings, especially in naturally ventilated (NV) school buildings, as students show significant adaptive behavior according to the indoor environmental changes.

2.2. Components of Indoor Environment. In this study, ventilation is considered as part of IAQ and daylighting as part of visual comfort (VC). The main four IEQ components are depicted in Figure 4 and discussed in this section concerning NV classrooms in school buildings.

\subsubsection{Thermal Comfort in Naturally Ventilated Classrooms.} Building user satisfaction with an indoor thermal environment is known as thermal comfort. According to the American Society of Heating, Refrigerating and Air-Conditioning Engineers (ASHRAE) Standard 55 [32], thermal comfort is the state of mind that expresses the satisfaction level of the building user with thermal surroundings inside the building. Langevien et al. [54] described that the three ways to assess human responses to comfort are thermal sensation, thermal acceptability, and thermal preferences. The perception of a building user regarding thermal surroundings is the user's thermal sensation. The degree up to which a building user accepts thermal surroundings is thermal acceptability. The ideal thermal environment according to the building user is the thermal preference of the user.

In India, National Building Code, 2016 [30] climate classification is used for the research while at a global scale most of the researchers use Koppen climate classification system. NBC climate classification is based on temperature and humidity levels. Koppen system is based on the coolest and the warmest month temperatures and precipitation criteria [55]. The general classification criteria of both the systems are jotted down briefly in Table 3 .

Thermal comfort depends on six parameters, out of which four are environmental parameters such as relative humidity, air speed, mean radiant temperature, and dry bulb temperature. Two personal parameters that majorly affect thermal comfort are metabolic rate and clothing [56]. In addition, four localized factors are also considered nowadays while assessing thermal comfort; these are vertical air temperature difference, radiant temperature asymmetry, floor temperature, and drafts [57]. Age, gender, race, individual condition, geographic location, cultural impact, type of work, and climate are various other factors that affect the occupant perception about thermal sensation $[58,59]$.

Pinto et al. [60] explain the relationship between ventilation and thermal comfort in a naturally ventilated school building. However, according to the authors, most of the teachers prefer a closed window to control outside noise and extra heat coming inside from the open window in NV schools. Wargocki and Wyon [61] discussed the impacts of the thermal environment over teaching and distraction in a naturally ventilated classroom. Performance and wellbeing are reduced due to poor thermal surroundings. Bargh and Shalev [62] presented that experiencing "physical warmth" can increase the positive feelings of occupants and, thus, potentially increase the performance.

Thermal comfort is also influenced by the behavioral adjustment and the physiological and psychological dimensions of the occupant. There are various models, indices, and charts to assess thermal comfort, such as Predicted Mean Vote (PMV), Resultant Temperature (RT), Effective Temperature (ET), Adaptive Model, Tropical Summer Index (TSI), Heat Stress Index (HSI), Wet-Bulb Globe Temperature (WBGT), Equatorial Comfort Index (ECI), Index of Thermal Stress (ITS), Wind Chill Equivalent Temperature (WCET), Predicted 4 Hour Sweat Rate $\left(\mathrm{P}_{4} \mathrm{SR}\right)$, India Model for Adaptive Comfort (IMAC), Percentage People Dissatisfied (PPD), Humidex, Standard Effective Temperature (SET), Predicted Thermal Sensation (PTS), and the Givoni model, the Mahoney model, and the Olgyay model.

Two models are used widely to assess thermal comfort. For conditioned buildings, PMV/PPD model given by P. Ole Fanger in 1970 is generally used. For nonair-conditioned buildings, the Adaptive model given by Richard J. de Dear [57] is used. The Adaptive model is based on real-time field studies, i.e., hundreds of studies showing the dynamic relation between the occupant adjusting the thermal environment by means of clothing, fans, operable windows, sunshades, etc.

Comfort estimation is more precise in adaptive approach, as it considers adaptations during the change in the thermal environment as the human body tries to maintain its temperature [63]. In NV schools, the adaptive model is the most suitable model to assess thermal environmental conditions.

International Organization for Standardization code ISO 7730 [33] is based on the PMV model. The limitation of the PMV model is that it is a chamber-method-based study and is not suitable for natural human interaction with the surroundings. It predicts a high level of dissatisfaction due to a lack of personal, social, cultural, and climate context.

Tropical Summer Index (TSI) is the index proposed by Sharma and Ali [64] to find the thermal comfort level along with the optimum conditions and range of thermally acceptable surroundings in warm-humid and hot-dry Indian climate. The Standard Effective Temperature (SET) model or Pierce 2-node model is another model developed by A.P. Gagge [65]. This model represents the human response to the thermal surroundings. This model's calculation is the same as the PMV model; the main difference is that it considers human physiology in measuring skin wettedness and temperature. ASHRAE accepted this model in 1996. However, later research tested this model with experimental data and explored that it underestimates skin wettedness and overestimates skin temperature.

Occupants living in NV buildings have a wider range of comfort temperature than the occupants living in air-conditioned buildings. Occupants overestimate and underestimate the thermal comfort, respectively, in warm places and cold places when using the PMV model. The adaptive model chart is based on extensive field studies throughout the globe which relates inside comfort temperature to prevailing outside temperature and defines $80 \%$ and $90 \%$ satisfaction zones. 


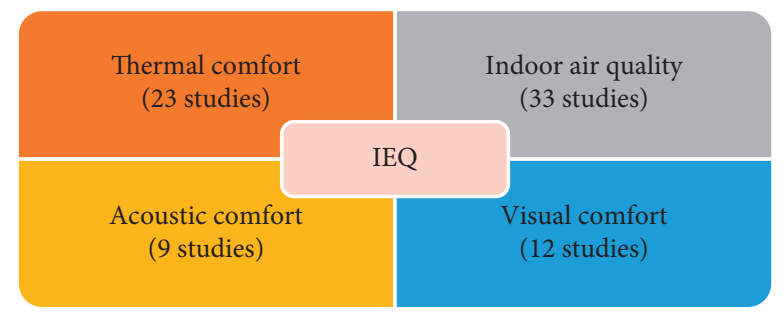

FIGURE 4: IEQ components and studies considered for review.

TABLE 3: Global and Indian climate classification.

\begin{tabular}{|c|c|c|c|}
\hline Region & $\begin{array}{l}\text { Major climate } \\
\text { group }\end{array}$ & Temperature (warmest month) & $\begin{array}{l}\text { Temperature (coolest } \\
\text { month) }\end{array}$ \\
\hline \multirow{6}{*}{$\begin{array}{l}\text { Global, according to } \\
\text { Koppen-Geiger Theory [55] }\end{array}$} & Tropical & $>18^{\circ} \mathrm{C}$ & $>18^{\circ} \mathrm{C}$ \\
\hline & Dry & $\geq 18^{\circ} \mathrm{C}$ & $\leq 0^{\circ} \mathrm{C}$ \\
\hline & Temperate & $\geq 10^{\circ} \mathrm{C}$ & $\geq-3^{\circ} \mathrm{C}$ and $<18^{\circ} \mathrm{C}$ \\
\hline & Continental & $\geq 10^{\circ} \mathrm{C}$ & $\leq-3^{\circ} \mathrm{C}$ \\
\hline & Polar and alpine & $\leq 10^{\circ} \mathrm{C}$ & $\leq 0^{\circ} \mathrm{C}$ \\
\hline & Highland & $\begin{array}{l}\text { Temperature is highly dependent on adjacent zone } \\
\text { traits and overall elevation }\end{array}$ & \\
\hline Region & $\begin{array}{l}\text { Major climate } \\
\text { zone }\end{array}$ & Mean of monthly temperature & $\begin{array}{l}\text { Mean of monthly relative } \\
\text { humidity }\end{array}$ \\
\hline \multirow{5}{*}{$\begin{array}{l}\text { Asia (India), according to NBC } \\
\text { 2016, India [30] }\end{array}$} & Hot and dry & $>30^{\circ} \mathrm{C}$ & $<55 \%$ \\
\hline & $\begin{array}{l}\text { Warm and } \\
\text { humid }\end{array}$ & $>30^{\circ} \mathrm{C}>25^{\circ} \mathrm{C}$ & $>55 \%>75 \%$ \\
\hline & Temperate & $25-30^{\circ} \mathrm{C}$ & $<75 \%$ \\
\hline & Cold & $<25^{\circ} \mathrm{C}$ & All values \\
\hline & Composite & $\begin{array}{c}\text { When } 6 \text { months or more do not fall in any of the } \\
\text { categories }\end{array}$ & \\
\hline
\end{tabular}

Fanger [66] gives an equation that is related to PMV to assess the percentage of the dissatisfied, known as the PPD (Predicted Percentage of Dissatisfied) model. More than $80 \%$ of people satisfied included population resulted as a satisfactory outcome for the PPD model. Draught sensation is due to the increased air velocity, and it can have both positive and negative effects on thermal comfort depending on the conditions. In normal conditions, draught sensation due to increased air flow rate can cause localized thermal dissatisfaction, but in warm conditions, it improves comfort. The draught model was included in ISO 7730 [33] and ASHRAE 55 [32]. Draught rating is the percentage of people dissatisfied with the air flow. India Model for Adaptive Comfort (IMAC) is prepared based on data collected from office buildings and does not consider other types of buildings. Manu et al. [67] stated that Indian subjects are less sensitive to temperature changes because of their adaptive behavior.

ISO 7730 [33] considers Fanger's model while ASHRAE 55 [32] is majorly focused on the adaptive model. EN15251 [68] modified as European Committee for Standardization (CEN) EN 16798 : 2019 [34] considers Nicol and Humphreys work as their basis. However, there is no globally accepted code as yet for naturally ventilated school buildings. Hence, there is the need to develop a code on IEQ in naturally ventilated school buildings.
Bronsema [69] recommended a separate comfort temperature for summer and winter. For school buildings, Bronsema recommends $22.1^{\circ} \mathrm{C}$ in winter and $24.5^{\circ} \mathrm{C}$ in summer. The author explains the interaction between the thermal environment and the surrounding air quality. CEN/ TC 156 technical report CR $1752-1998$ suggested $23.5^{\circ} \mathrm{C}$ temperature in summer and $20^{\circ} \mathrm{C}$ temperature in winter for European schools as a comfortable temperature.

Seppanen and Fisk [70] did a meta-analysis of studies, which shows that SBS symptoms increase by $12 \%$ for every $1^{\circ} \mathrm{C}$ rise in temperature over $28^{\circ} \mathrm{C}$. At $21.5^{\circ} \mathrm{C}$, the occupant performance is optimal. However, temperatures less than $20^{\circ} \mathrm{C}$ and more than $23^{\circ} \mathrm{C}$ can affect the performance of the occupant by $10 \%$.

Thermal comfort can impact the performance and wellbeing of occupants thus influencing their morale, and this simultaneously increases complaints regarding indoor conditions [71]. Nakano et al. [72] explained that high temperature impacts mathematical ability. By measuring brain-blood flow, it is found that due to mental load, the performance of teachers is reduced in high temperature. Some studies say that due to a lack of control over the thermal environment, absenteeism is increased, thus resulting in lower performance and achievement. Increased controls can increase thermal comfort. However, Melikov et al. [73] and Newsham et al. [14] found that access to such 
controls did not increase or decrease thermal and visual comfort. Andersen [74] researched personal control of thermal comfort using ventilation and its impact on occupant comfort by using an online survey. Occupants feel more comfortable in any environment when they have the selfability to control the environment. Occupants in NV buildings are more satisfied than occupants of mechanically ventilated buildings.

Singh et al. [75] tested 900 subjects in naturally ventilated classrooms for their behavioral adaptations. They found that in NV buildings, students are more adaptive in behavior and can easily modify their comfort by opening windows, switching-on fans, and changing clothing levels. Noda et al. [76] tested 6 classrooms in 3 schools for thermal comfort by both subjective and objective assessment. 97 students of age 9-11 years who participated in the study were having a wide range of comfort perception in the classroom. Singh et al. [77] reviewed previous literature on thermal comfort in classrooms. In India, most of the schools are naturally ventilated, and the students are quite adaptive in behavior. The authors have suggested preparing standards for different age groups and proposed thermal comfort equations based on the adaptive approach for classrooms.

\subsubsection{IAQ in Naturally Ventilated Classrooms. Quality of} indoor air is one of the most important components inside the built environment. The combined behavior of various factors and dynamic interaction with other components make it difficult for users to identify IAQ problems [78]. In the different indoor environments, there are different sources of pollution depending upon the building type (residential, school, office, market). Kamaruzzaman [79] studied workplace conditions and explained that most studies discuss reactive measures regarding IAQ and that very few studies describe the building construction and design to enhance IAQ. Except for indoor sources, outdoor pollution also affects the quality of indoor air. Bad IAQ can cause sick building syndrome (SBS) effects in the occupant, which in long term can be converted into building-related illness (BRI) and become harmful to one's health. Poor IAQ potentially influences the performance of students and teachers. A negative effect like sickness absence in school is common due to poor IAQ and inadequate ventilation.

Stetzenbach et al. [80] reported that air freshness can be measured by measuring suspended Particulate Matter (PM) and volatile organic compound (VOC) concentration indoors. Mendell and Heath [20] studied air quality, thermal comfort, and their impact on students' performance. More indoor humidity and increased organic pollutants are the reason behind increased respiratory illness and asthma. Heinsohn and Cimbala [81] explored the relationship between newer design solutions like underfloor air diffuser, displacement ventilation, and their impacts on indoor air pollution. However, maximum schools did not adopt these solutions. To improve IAQ, identification of the source of contamination, i.e., the flooring material type, paint on walls and desk, and equipment used in class, is important. These sources can affect children's health severely and increase the chances of respiratory illness and asthma.

Many schools use carpets to enhance the indoor air quality in classrooms. However, Fisk [19] found that removal of carpet from indoor can improve performance and potentially reduce the level of physical contaminants. Removing carpet resulted in better air quality and fewer headaches, dizziness, and SBS symptoms. Removal of carpet enhanced performance, i.e., $6.5 \%$ of text-typing amount, $3.1 \%$ on a timed test, and $3.8 \%$ score in logical reasoning. After self-assessment, it is found that reduced incidents of headaches are the reason for enhanced performance after removing the carpet. Tortolero et al. [82] examined carpets of 80 classrooms to test surface loading due to organic pollutants. $30 \%$ of the examined classrooms had an unacceptable level of insect and fungal allergens. Foarde and Berry [83] compared tiled floor classroom with carpet floor classroom. The tiled floor classroom had a higher concentration of aerosol particulate. The carpet floor classroom had a highly contaminant sink and high surface loading. Between teacher-student performance and the type of flooring, there are various acoustics and psychological differences. Bullock [84] found that in hard tiled floor classrooms students score higher in mathematics than in carpeted floor classrooms. However, out of 111 classrooms, only $5 \%$ of the classrooms had carpet; this limits the validity of the study.

Schneider [51] conducted a study using Chicago and Washington DC school teachers to find out the condition of the school environment, the relation between IEQ, and the impact on teachers' health. Referring to school facilities, most of the health complaints were related to air quality. More than $50 \%$ of teachers report a problem and one-third of the teachers have poor health conditions due to poor school environment. Kielb et al. [48] surveyed teachers of primary and secondary schools in New York State. Of 501 teachers, most of them say that classroom air quality is not good. Approximately, $40 \%$ of teachers reported at least one health symptom. Headaches, allergies, and throat irritation are the most common symptoms among them. Classrooms have at least two related symptoms, and the strong reasons are dust, mold, paint odors, and other indoor pollutants.

Wyon [21, 85] reported that poor air quality can influence worker comfort and potentially reduce performance by $6 \%$. Lorsch and Abdou [86] reported that people feel more concentrated and comfortable when air conditioning is used. Performance of conditioned space user is increased between 5 and $15 \%$. Without humidity control, teachers experience discomfort in the summer months. For an ideal learning environment, humidity control plays a crucial role in achieving better IAQ. Cross ventilation is generally responsible for maintaining the classroom environment in $\mathrm{NV}$ classrooms. Air enters through doors, windows, and cracks, and fresh air occupies the room volume, meanwhile stale air exits through the opposite side openings, if any. An illustration is presented in Figure 5 for a better understanding. A primary school classroom design for 40 students was drafted according to IS 8827-1978 [87]. According to the recommendation of the standard, the classroom of size $(6100 \mathrm{~mm} \times 7300 \mathrm{~mm})$ has three ceiling fans. Each fan is of 


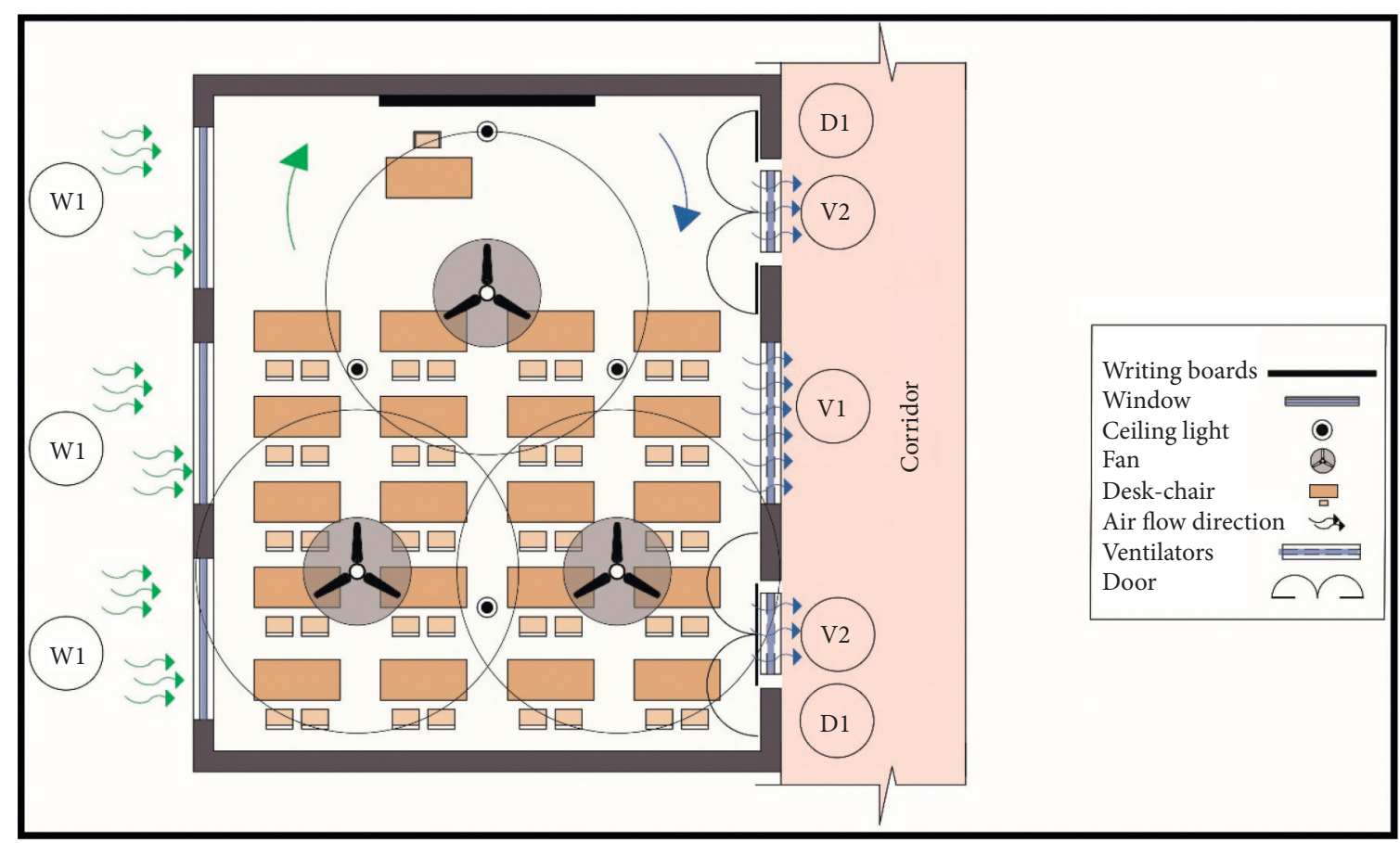

FIgURE 5: Air flow in the naturally ventilated classroom.

$\emptyset 1200 \mathrm{~mm}$ and effectively circulates air in the circle of $\emptyset$ $3600 \mathrm{~mm}$, thus covering the whole occupied area of the classroom showing better air circulation inside. Windows (W1) of size $1800 \mathrm{~mm} \times 1200 \mathrm{~mm}$, ventilators of sizes $\{1800 \mathrm{~mm} \times 600 \mathrm{~mm}(\mathrm{~V} 1)$ and $1200 \mathrm{~mm} \times 600 \mathrm{~mm}(\mathrm{~V} 2)\}$, and door $\{1200 \mathrm{~mm} \times 2100 \mathrm{~mm}$ (D1) $\}$ help in regulating fresh air from outside by replacing indoor stale air.

For controlling pollutants through the reduction approach, ASHRAE 62.1-2013 [76] specifies minimum outdoor air supply rates in buildings. Three liters per second per person outdoor air is the minimum requirement for classroom ventilation. Ventilation flow rate $<0.152 \mathrm{~m}^{3} / \mathrm{s}$ is termed as "Still Air"; this is harmful, as pollutants remain suspended in the air and occupants breathe them in, which can harm their health and result in discomfort. Technical report CR-1752 (1998) [88] developed by European committee CEN/TC 156 classifies ventilation change rate for classrooms, ranging from 0.47 to 1.18 cubic foot per minute/ square foot into three categories, i.e., $15 \%, 20 \%$, and $30 \%$ discomfort [89]. The values of the various gases for good indoor air quality for humans are mentioned in Table 4 . The values can serve as a reference for NV classrooms as they are determined for residential buildings.

Bronsema et al. [69] developed a design guide to assess the performance of buildings for comfort and health. Based on the US EPA standard and World Health Organization (WHO) recommendation, upper limits of major and minor influential contaminants are decided. EPA recommended that $\mathrm{PM}_{10}$ must be lower than $150 \mu \mathrm{g} / \mathrm{m}^{3}$ in 24 hours, while inhalable $\mathrm{PM}_{2.5}$ must be restricted up to $35 \mu \mathrm{g} / \mathrm{m}^{3}$ in 24 hours. However, the WHO recommends lower levels for $\mathrm{PM}_{10}$ ranging less than $20 \mu \mathrm{g} / \mathrm{m}^{3}$. Occupational Safety and Health Administration (OSHA) and NIOSH determined a safe exposure range for different contaminants. NIOSH uses 10 hours' and OSHA uses 8 hours' exposure period for concentration limits [69].

According to the Indian Society of Heating, Refrigerating and Air Conditioning Engineers (ISHRAE) standard $10001: 2019$ [31], there are two ways to measure and monitor IAQ; in the first way, major IAQ parameters are tested two times in each season and three times a day (i.e., 9:00-11:00 AM, 12:00-2:00 PM, and 3:00-5:00 PM), a total of 18 results per year. All minor IAQ parameters are tested 2 times a year and 3 times a day, up to a total of 6 results per year. Microbial counts are tested 2 times a year. The second way suggests continuous monitoring of major IAQ parameters, i.e., a minimum of one reading per hour round the year and one reading for cross verification of the system -8760 results per year can be recorded. All the minor IAQ parameters are tested 2 times a year and 3 times a day-a total of 6 results per year are accumulated. Formaldehyde and microbial count can be tested in the first way. But this is not applicable to school buildings; therefore, there is a need to research and update the standards for school buildings.

Schweiker et al. [90] found that during a controlled study in a test chamber, subjects had higher skin temperature when windows are not operable. Subjects drank more water during that period possibly due to high air pollution inside. Barrett et al. [91] suggested that, for avoiding poor IAQ, glare, and overheating later, one must consider building orientation, shading design, devices, and the position and size of windows at the design stage. Heschong et al. [92] found that operable windows can enhance student performance and can achieve $7 \%$ better results in mathematics and reading than those in fixed window classrooms. Daisey et al. [93] reviewed many 
TABLE 4: Air quality parameters and their suitable range.

\begin{tabular}{|c|c|c|c|c|c|}
\hline \multirow{2}{*}{\multicolumn{2}{|c|}{ Parameters }} & \multicolumn{4}{|c|}{ Suitable concentration } \\
\hline & & EPA & WHO & OSHA & Canadian \\
\hline \multirow{3}{*}{ Major influential } & $\mathrm{CO}_{2}$ & - & - & $5000 \mathrm{ppm}$ & $3500(\mathrm{~L})$ \\
\hline & $\mathrm{CO}$ & 9 ppm & $90 \mathrm{ppm}$ [15 min] & $50 \mathrm{ppm}$ & $11 \mathrm{ppm}[8 \mathrm{~h}]$ \\
\hline & $\mathrm{PM}_{2.5}$ & $15 \mu \mathrm{g} / \mathrm{m}^{3}[1 \mathrm{yr}]$ & - & $5 \mathrm{mg} / \mathrm{m}^{3}$ & $0.1 \mathrm{mg} / \mathrm{m}^{3}[1 \mathrm{~h}]$ \\
\hline \multirow{5}{*}{ Minor influential } & $\mathrm{PM}_{10}$ & $\mu \mathrm{g} / \mathrm{m}^{3}$ & - & - & - \\
\hline & $\mathrm{CH}_{2} \mathrm{O}$ (formaldehyde) & - & $0.081 \mathrm{ppm}[30 \mathrm{~min}]$ & $0.75 \mathrm{ppm}$ & $0.1 \mathrm{ppm}(\mathrm{L})$ \\
\hline & $\mathrm{SO}_{2}$ & $0.03[1 \mathrm{yr}]$ & $0.048 \mathrm{ppm}[24 \mathrm{~h}]$ & 5 & $0.019 \mathrm{ppm}$ \\
\hline & $\mathrm{NO}_{2}$ & $0.05[1 \mathrm{yr}]$ & $0.1 \mathrm{ppm}[1 \mathrm{~h}]$ & $5 \mathrm{ppm}(\mathrm{C})$ & $0.05 \mathrm{ppm}$ \\
\hline & $\mathrm{O}_{3}$ & $0.12[1 \mathrm{~h}] 0.08$ & $0.064 \mathrm{ppm}[8 \mathrm{~h}]$ & $0.1 \mathrm{ppm}$ & $0.12 \mathrm{ppm}[1 \mathrm{~h}]$ \\
\hline
\end{tabular}

studies and found that by increasing natural ventilation, there is an increment of about $14 \%$ in speed and performance of the schoolwork. The review revealed that air quality in schools is very poor when compared to offices, as schools are neglected severely.

Haghihat and Donnini [94] reported that if temperature and ventilation conditions are under the direct control of building space users, less health symptoms, increased performance, and reduced absenteeism are some major outcomes. When air quality is enhanced due to controlled ventilation and temperature, the worker's performance increases up to $6.5 \%$. However, sometimes energy consumption is also increased due to improved ventilation. However, if schools are properly designed initially, NV schools can save a lot of money along with providing much better comfort inside the classrooms. Yu et al. [95] established a fresh air system filter selection method and proposed a method to find out outdoor $\mathrm{PM}_{2.5}$ concentrations.

2.2.3. Ventilation. Ventilation is the flow of outdoor air indoors for diluting the indoor air and increasing air quality primarily and for removing stale air inside. Ventilation is generally considered a part of Indoor Air Quality. Studies done in the past reported that carbon dioxide concentration is an IAQ indicator that depends on ventilation [96]. Ventilation also affects the thermal comfort inside a building by dehumidification of the space. According to ASHRAE 62.1 [37], ventilation supplies or removes air from indoors to maintain humidity, air contaminant levels, and temperature inside the occupied space.

Ventilation is divided into four types: (i) natural ventilation, (ii) mechanical ventilation, (iii) mixed-mode ventilation, and (iv) infiltration. However, the present review focuses on natural ventilation only, which is achieved by passive design and approaches like stack effect, wind pressure, and diffusion.

Kajtar et al. [97] experimented and found the effect of carbon dioxide on human health indoors and the effect of fresh air supply rate indoors. Poor ventilation increases carbon dioxide concentration in the classroom. Based on ventilation requirement in schools, UK Building Bulletin 101 [98] recommend that the average concentration of carbon dioxide during operational hours in school should not exceed $1500 \mathrm{ppm}$. It also sets out the minimum supply rate of 3 liters/second per person fresh air in the classroom.
Shaughnessy et al. [99] examined one classroom among 87 schools for their carbon dioxide levels. The study shows that test scores improved with more ventilation. Croome et al. [100] explained that occupants frequently complain about odors and carbon dioxide but complain less about higher organic pollution and poor ventilation rates indoors. Building users change their behavior, feel uncomfortable, and sometimes show ill-health symptoms without realizing that these are due to ventilation rate and air quality [81].

Shendell et al. [101] nudge the idea of IAQ relation with ventilation through the concentration of carbon dioxide present indoors. Poor ventilation and bad IAQ is the reason behind absenteeism in schools. They found that absenteeism is increased by $10-20 \%$ when carbon dioxide is above $1000 \mathrm{ppm}$ due to poor ventilation rates. Poor ventilation is the major cause of absenteeism and influences the outcomes of the education system negatively by affecting teachers and students. Wargocki and Wyon [61] found that adequate ventilation rates can reduce stress. Fresh air reduces stress; students feel less hunger in properly ventilated classrooms. Performance is severely affected by air flow rates in classrooms. Liang et al. [56] studied on indoor carbon dioxide level as an indicator for ventilation requirement. Ventilation rates could not be predicted accurately on the basis of the carbon dioxide concentration they added. Araya [102] found that natural ventilation is not a good ventilation technique for schools situated at polluted locations.

Haghighat and Donnini [94] studied air distribution techniques and ventilation control display. The relationship between IAQ and ventilation is complex; however, greater comfort with IAQ is perceived by building occupants for a higher ventilation rate. Demand Control Ventilation (DCV) products are available readily in the market for $\mathrm{CO}_{2}$-based ventilation purposes, but updates are required. ASHRAE [37] codes are used for designing ventilation systems globally. Peng et al. [103] proposed an integrated low-energy ventilation (ILEV) system for primary schools in cold regions. ILEV can increase indoor air quality by using plants in sunspaces for absorbing $\mathrm{CO}_{2}$. ILEV also increases thermal comfort inside classrooms with saving of approximately $88 \%$ energy and providing economic benefits up to 42 years with 8 years payback period. However, this study majorly focused on plant's ability in classrooms, which depends upon various assumptions. Sunlight is low in cold climates, which can 
potentially reduce the photosynthesis speed in plants. Most of the educational buildings in India work on natural ventilation and some are using mixed-mode ventilation techniques. Therefore, there is a need to develop code/ guidelines for NV school buildings.

\subsubsection{Visual Comfort in Naturally Ventilated Classrooms.} Good visual environment provides comfort due to the adequate level of task visibility and lack of strain on the occupant's eyes. Visual comfort is essential for productivity and health [104-106]. According to EN 12665, 2002 [35], visual comfort is "a subjective condition of visual wellbeing induced by the visual environment."

Research shows that daylighting enhances occupant productivity, reduces stress, and is advantageous for an occupant's wellness [107]. Daylight is also associated with the positive attitude of an occupant, negligible eye strain, reduced fatigue, and lower error and defects in work. Alrubaih et al. [108] described two types of natural daylighting systems in buildings. Window opening is an example of a side lighting and skylight or any other opening in the building roof is used for providing top lighting.

Lighting design standards in India are National Building Code (NBC) 2005 (Part 8, Section 1) [109], SP-41 [29], IS: 2440 [110], and IS: 7942 [111]. Illuminating Engineering Society of North America (IESNA), International Organization for Standardization (ISO), Commission Internationale de l'Eclairage (CIE), Association Argentina de Luminotécnia (AADL), and many others are some bodies that provide international standards. UK Building Bulletin 90 [112] guides to create a good lighting design for schools. In six sections, the Bulletin covers most aspects from lighting design to integration of artificial lighting and natural daylight. It sets out the standard maintained Illuminance of 300 lux in the classrooms. Similarly, Jain et al. [113] have developed an android app for integrating natural daylight with artificial lighting for Improving Building Energy Efficiency of Residential and Commercial Buildings during the daytime in all Sky Conditions of the United Kingdom.

Abdou [114] discussed the effect on wellbeing, comfort, and performance due to the physical environment of lighting. Rice [115] explored that there is a difference in views; some people say that there is no effect of illuminance, color, and lighting on them, but others claim that their mood is directly impacted by these factors. Therefore, the performance of such people is affected severely due to variation in mood. Inadequate lighting can cause various mental and physical effects, thereby rendering the building as one of poor quality. Hanford and Figueiro [116] also supported the fact that illumination level, lighting spectral distribution, and design can potentially affect mood and thus the performance of building users. Ocvirk et al. [117] explained that bright colors and strong lighting can enhance the comfort and happiness of building users. Aries et al. [118] experimentally found that good control over lighting and bright lights can potentially improve occupant mood and thus performance. Therefore, classrooms must be designed to cater to all possible functions at all different levels to increase psychological benefits. Overall, classroom illumination is important for enhancing positive attitude in teachers and students rather than focused light on some areas in the classroom [119].

Nicol et al. [120]worked on daylight effects and effects of blinds on lighting. The outcome showed that those users who can control natural daylight easily are more comfortable in comparison to other users who are unable to control it. However, the illuminance level is not in adequate control according to the outside lighting level. The orientation of windows is important along with window control strategies for natural daylight [121]. Bessoudo et al. [122] found that the southern part of the building received more direct sunlight than the northern part. Therefore, to reduce glare problems associated with direct sunlight, southern facade windows need shading devices and more blinds than the northern sides in a building. More use of glass in building facade and poor design increases glare problems and thus increased blinds and shadings. This reduces natural daylight indoors and slowly artificial light usage is increased. This will lead to excessive energy consumption and increased carbon dioxide emission [123].

Most people prefer natural daylight over artificial light as it reduces stress levels and enhances health conditions. Good integration of both natural and artificial light can enhance the performance and productivity up to $15 \%$ and $20-26 \%$. Ashok Kumar et al. [124] have developed an android app for integrating daylight with artificial lighting for improving building energy efficiency during daytime in all climates for India.

Ghisi and Tinker [125] proposed a method to find out the energy-saving potential when daylight was used; their results showed $11 \%-86 \%$ of reduction in electricity consumption for lighting due to daylight.

Solar heat gain and daylight glare produce ill effects; on the other hand, dynamic lighting spectrum and outside view influence building users positively [126]. Hathaway [127] connected natural daylight with the performance of building users in the school. The visual environment of the classroom affects the learning, attendance, and thus performance of students and teachers. Rice [115] found that when teachers and students can easily control their lighting environment, they feel that a more positive and adjusted, appropriate level of lighting helps them in increasing their performance. However, Lewy et al. [128] found that during summers, surplus sunlight illuminance can create uncomfortable conditions for students and teachers in classrooms. Aries et al. [118] pointed out that there are fewer scientific studies around the globe that are well documented and have statistically proven the relation between daylight and associated health effects, especially depression. In a building occupant survey in Bhopal, people consider daylight and lighting a more important component of IEQ [129]. The human eye can adapt to changes quickly, but effects like disturbance while working, stress, and eye damage can occur due to frequent change in natural light intensities. Simultaneously, artificial light is also dangerous for human health, as it contains ultraviolet rays. Eyestrain, fatigue, and frequent headaches are general symptoms caused by poor artificial lighting [92]. 
For better learning outcomes, there must be controlled daylight and adequate artificial lighting in the whole classroom equally. Eyestrain, headaches, fever, and muscular pain are common symptoms due to a lack of lighting design and control [119]. Reinhart focused on luminance ratio as an important factor while designing light. Luminance ratio is the ratio between the darkest and the brightest points in an area. For safety when performing various tasks, a minimum level of illuminance, defined by various building and lighting codes, is required. NBC, 2016 [30] prescribes the minimum illuminance levels (200 lux) in classrooms. A general illustration of natural daylight and artificial lighting in a naturally ventilated classroom is shown in Figure 6. The classroom shown in Figure 6 will have sunlight during morning and afternoon times through windows and doors. Thus, one can easily save energy by reducing artificial lighting in the classroom. Morning daylight will provide excellent light and generate low heat, which is healthy for occupants.

Daylight harvesting is one of the best solutions to save $10 \%$ of energy, which is utilized in artificial lighting. Li et al. [130] designed and analyzed an active daylight harvesting system for utilizing daylight. Occupancy sensors, time scheduling, daylight dimming, bi-level switching, and demand lighting are the various types of lighting control.

Common lighting strategies are scheduling, tuning, daylighting, lumen maintenance, demand limiting, and adaptation compensation. By choosing the proper strategy and control system, one can reduce the lighting load of a building. There are very limited studies around the globe that show the relationship between artificial light, daylight, and associated comfort along with long- and short-term health impacts in school buildings.

\subsubsection{Acoustic Comfort in Naturally Ventilated Classrooms.} Acoustic comfort is the quality of the building to safeguard its inhabitants from surrounding noises and offer them a better acoustic environment in which they can easily communicate without any extra effort. Generally, occupants have minimum control over indoor acoustic conditions and their sources. People living in noisy indoors may feel stress, hypertension, rage, sleep disturbances, ear-aches, etc., and generally be more irritable and talk loudly as being habitual to shouting [131-133]. Hearing sensitivity is impacted by sound pressure waves. Physical characteristics of sound, source distance, and space conditions are the major factors that affect sound quality. Major space conditions are sound absorption, reverberation time, and insulation. Receiver conditions and age also play a vital role in hearing and thus mutate their perceptions regarding the surrounding environment $[134,135]$.

Studies in Germany show that occupants with low income are prone to acoustic discomfort more than highincome group occupants [136]. Occupants can have concentration impairment issues and other mental problems when they are continuously exposed to noises. Acoustic comfort directly affects occupant's productivity, comfort, and health $[137,138]$. UK building bulletin 93 [139] is focused on the acoustic design of schools. It describes the minimum acoustic performance standards in school buildings for a better teaching and learning experience. It sets out the upper limit of $35 \mathrm{~dB}$ for the indoor ambient noise level of new build classrooms.

The current education system is using the digital mode of teaching in which different audio affects listeners in different ways as the perception and physiological mechanism of every listener is different. Bad acoustics can result in reduced teacher and student performance, less student focus, tiredness in listeners, and low quality of communication. According to Tiesler et al. [140], it is very difficult for students and teachers to ignore the unwanted sound and background noise. In the sitting position, it is difficult for teachers to gain the attention of the class as voice is depressed by the various indoor and outdoor noises. The depression of the teacher's voice increased for students sitting at distant positions as distance influences sound pressure level [141]. To cater to the needs of the classroom, teachers generally teach in a standing position to effectively convey their lessons and gain proper attention from the students sitting in the classroom. Indoor-outdoor noises decay the quality of teacher's voice up to some extent; Figure 7 is illustrating the noise scenario. Noise is coming from outer sources by infiltration from windows, vents and doors, and indoor sources such as students talking to each other during the lecture.

Serra and Biassoni [142] revealed that higher cost impacts the acoustic quality in US schools. Acoustic problems must be considered during the design stage of a building and for that, it is essential to access and define as to what is going to happen outdoors and indoors [143, 144]. For human hearing, $20-20,000 \mathrm{~Hz}$ is the comfortable sound range. For clear communication and normal speech, the background noise level must be less than $45 \mathrm{~dB}$ in educational buildings. Reverberation time must be between 0.6 and 0.8 for better listening in theoretical classrooms. For the acoustic design of schools, the American National Standards Institute ANSI/ ASA S12.60-2010/Part-1 standard [38] recommends that background noise must be limited to $35 \mathrm{~dB}$ in school buildings and a reverberation time of 0.60 seconds.

Acoustic comfort is the least researched component among the major components of IEQ in India. Proper testing and evaluation of noise need to be performed at the building site before construction, and the results after the construction need to be verified to create some index or model to predict the noise, particularly along highways and noisy places. Thus, there is a need to carry out further research in this domain.

2.3. Impact of COVID-19 on School Buildings. Due to the COVID-19 pandemic, most of the governments temporarily closed schools in an attempt to reduce the spread of COVID19. Currently, more than $60 \%$ of students enrolled globally in level 0 to level 3 (International Standard Classification of Education) are affected [145]. At the global peak of COVID19, from 30 March 2020 to 05 April 2020, 91.3\% (more than 


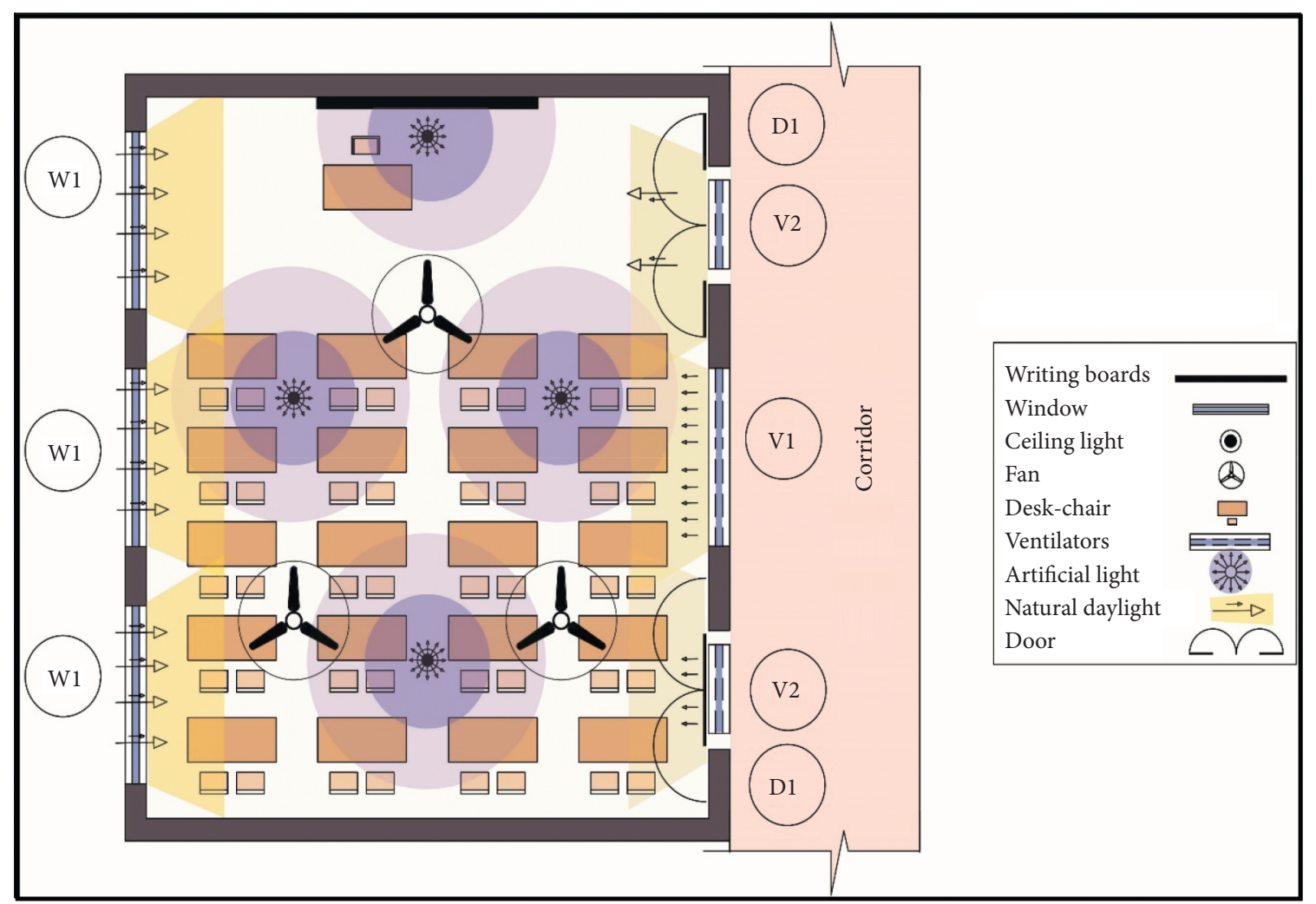

FIGURE 6: Lighting in a naturally ventilated classroom.

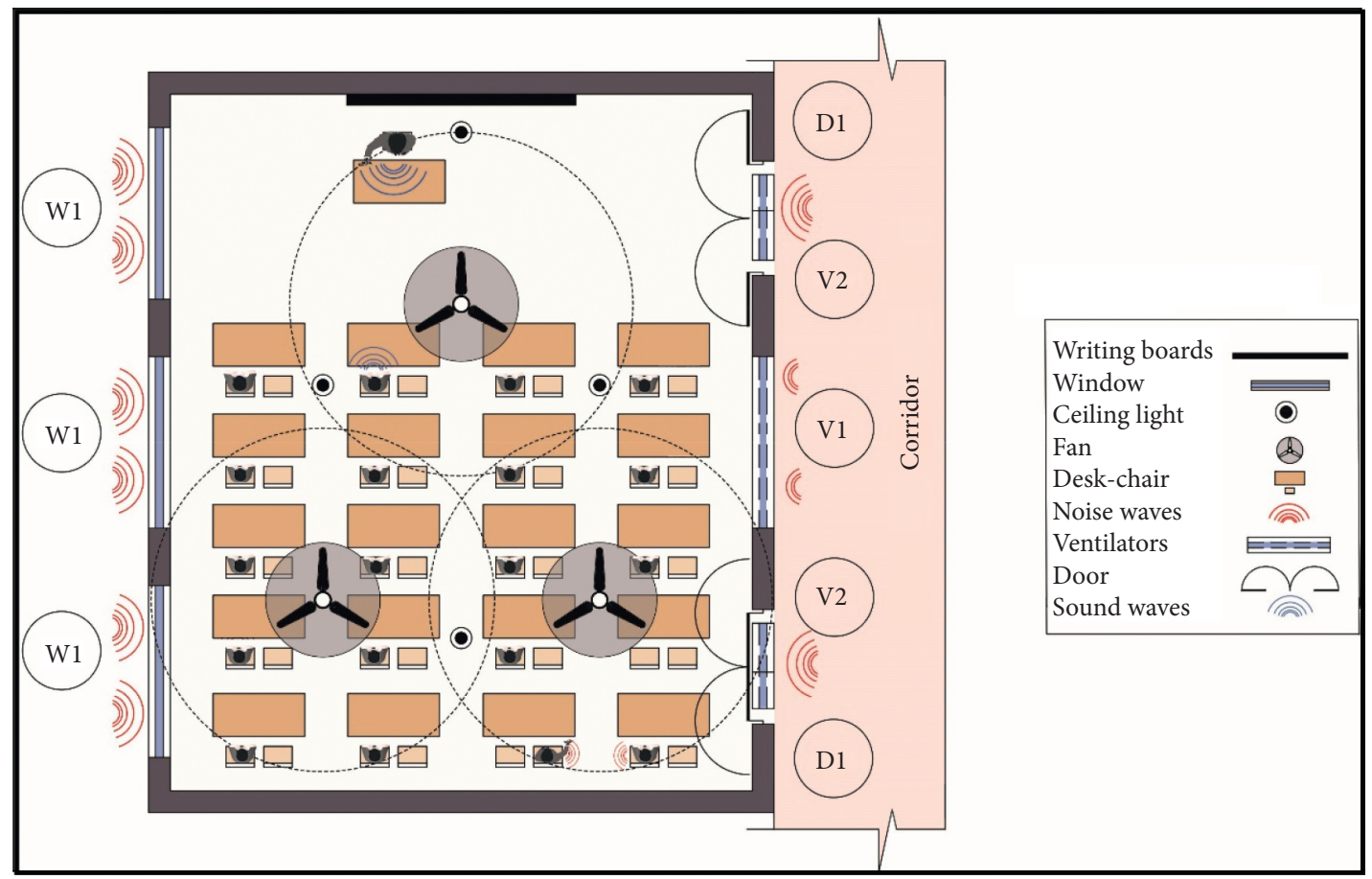

FIGURE 7: Sound interrupted by indoor-outdoor noise in the naturally ventilated classroom.

1.5 billion students) of the total enrolled learners are affected across 194 countries due to the lockdown situation. The primary health concern is to prevent the spread of COVID19; however, due to the disrupted education system, every government wants to reopen schools as soon as possible. For considering the stakeholder's consent, it is essential to quickly gather information and perform rapid response surveys. An UNESCO report [145] points toward "How to 
Reopen Schools," considers 6 key dimensions, out of which 2 dimensions are wellbeing/protection and learning, and these depend upon IEQ. As COVID-19 is spreading through contaminated air, natural ventilation is not good for classrooms. Currently, there is no study related to COVID19 impact on the school classroom. Some regulatory bodies $[146,147]$ emphasize on maintaining good IEQ to reduce the spread of COVID-19 in the current situation, but they are not specifically for school buildings. Thus, it is important to carry out research, particularly for school classrooms, as students are the most vulnerable group in the current situation.

\section{Discussion and Conclusion}

This paper presented a systematic review of the studies around the globe related to indoor environmental quality components, namely, thermal comfort, indoor air quality, ventilation, visual comfort, daylight, and acoustic comfort in naturally ventilated school classrooms. SBS and BRI are also discussed in brief for a better understanding of the need for IEQ in naturally ventilated school buildings. It is found that there are no globally accepted codes and Indian standards till date that can serve as the basis for maintaining/providing good IEQ in NV school classrooms. Present conditions indicate that there is a dire need for more scientific efforts to achieve more accurate comfort limits. A more precise and accurate methodology is needed to standardize the process conforming to all types of climates.

Although some codes separately deal with individual components or with multiple components, comfort limits vary widely in different standards. Therefore, more studies are needed to explore the IEQ in NV school classrooms worldwide for developing country-specific guidelines. In India, the studies on IEQ are scarce and scattered.

Therefore, country-specific IEQ codes and guidelines in relation to naturally ventilated school buildings need to be developed. To accomplish this, a real-time assessment of IEQ and comfort in NV classrooms is essential.

Similarly, poorly ventilated buildings and systems enhance the risk of indoor virus transmission. Airborne transmitted diseases in the form of aerosols (nuclei droplets), such as MERS (Middle East Respiratory Syndrome), SARS (Severe Acute Respiratory Syndrome), and COVID19 , have confirmed that in the future these kinds of viruses will be a great danger. In general, there are two routes of infection spread in closed spaces. First, aerosol generated by the infected person is directly inhaled by the exposed person. This occurs when the distance between the infected person and the exposed person is less than $1.5 \mathrm{~m}$. Second, aerosol generated by the infected person's activities (like sneezing, coughing, etc.) is mixed in the room air and with air flow; the droplet nuclei travel and enter into the system of the exposed person. This occurs for large distances, generally greater than $1.5-2.0 \mathrm{~m}$ [148, 149]. Moharir et al. [150] found that if the distance is more than $2.5 \mathrm{~m}$ and the contact time between any COVID-19 patient and an exposed healthy person is less than 20 minutes inside a room, the chances of virus transmission through the air is low. Figure 8 shows the reduction of infection with an increase in the distance between the infected and the healthy person.

The transmission of Corona virus in the school buildings is a challenging issue and there is no proper evidence to prevent the transmission of this type of pandemic inside naturally ventilated school buildings. The researchers are trying to find solutions for controlling the transmission of Corona virus among humans and to find escape routes/ technologies to save the students' lives if the virus has entered the buildings. Some researchers are working on finding ways to prevent the transmission of Corona virus from infected humans due to inhalation of airborne particles indoors. Therefore, the best way to escape from the Corona virus inside the buildings is to bring in fresh air after proper filtration and remove the infected inside air through an exhaust (ventilation) into open space via ducts, etc. Many air filters are available to prevent the polluted air to filter out the $\mathrm{PM}_{2.5}$ particles, etc. The existing air filtration techniques are not suitable to filter out the Corona virus because the virus size is less than $0.1 \mathrm{~nm}$ and most of the available air filters' porosity is approximately $0.3 \mathrm{~nm}$. Therefore, the prevention strategy during COVID-19 in naturally ventilated school buildings is also to be developed.

Students are the future of any country; it is, therefore, essential to provide them a healthy and comfortable learning environment. This article is a primary step in this direction. A schematic diagram of the proposed filtration system for a naturally ventilated classroom is depicted in Figure 9.

The following conclusions can be drawn from the review:

(i) There are many international studies on IEQ; however, there are very few studies for naturally ventilated Indian school buildings.

(ii) Comfort temperature among the subjects varies largely; so, for better prediction, it is necessary to develop a country-specific comfort model for school buildings.

(iii) None of the studies tried to find out the interrelation between different components of comfort in school buildings. Most of the studies consider different seasons but a few studies consider the whole year; as temperature varies throughout the year, it is necessary to consider daily, weekly, monthly, and seasonal changes.

(iv) There are fewer IEQ studies reported in developed countries. Achieving SDG's 4th goal is not enough; IEQ must be considered as an important component in developing the education system, and stakeholders must be trained and informed regarding this.

(v) Hawthorne effect is neglected in most of the studies. Few multi-factor studies are available relating to IEQ parameters. So it is very difficult to comment on the combined effect of parameters on students in school classrooms. Therefore, there is a need to develop a methodology for the combined impact of the parameters on IEQ. 


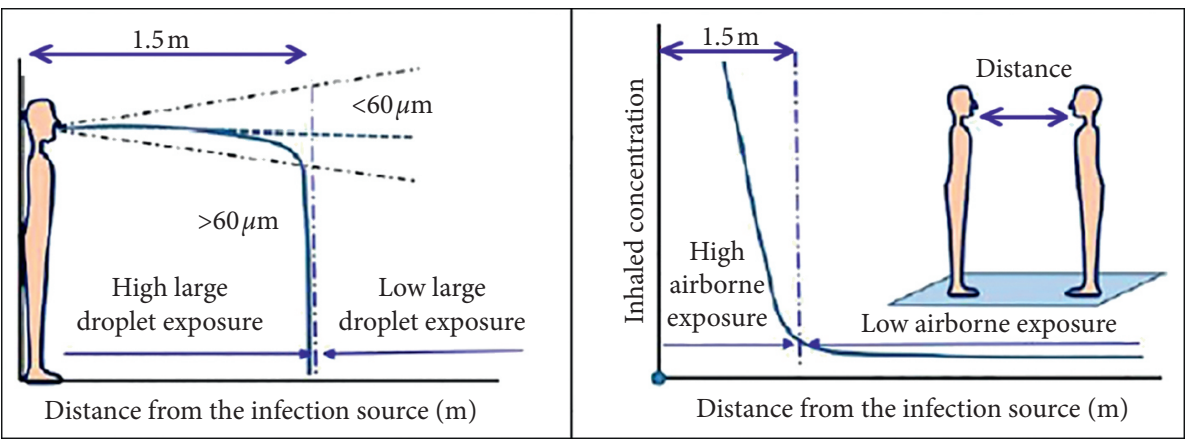

FiguRE 8: Short-range, close contact, and long-range exposure of droplets and droplet nuclei (source: [151]).

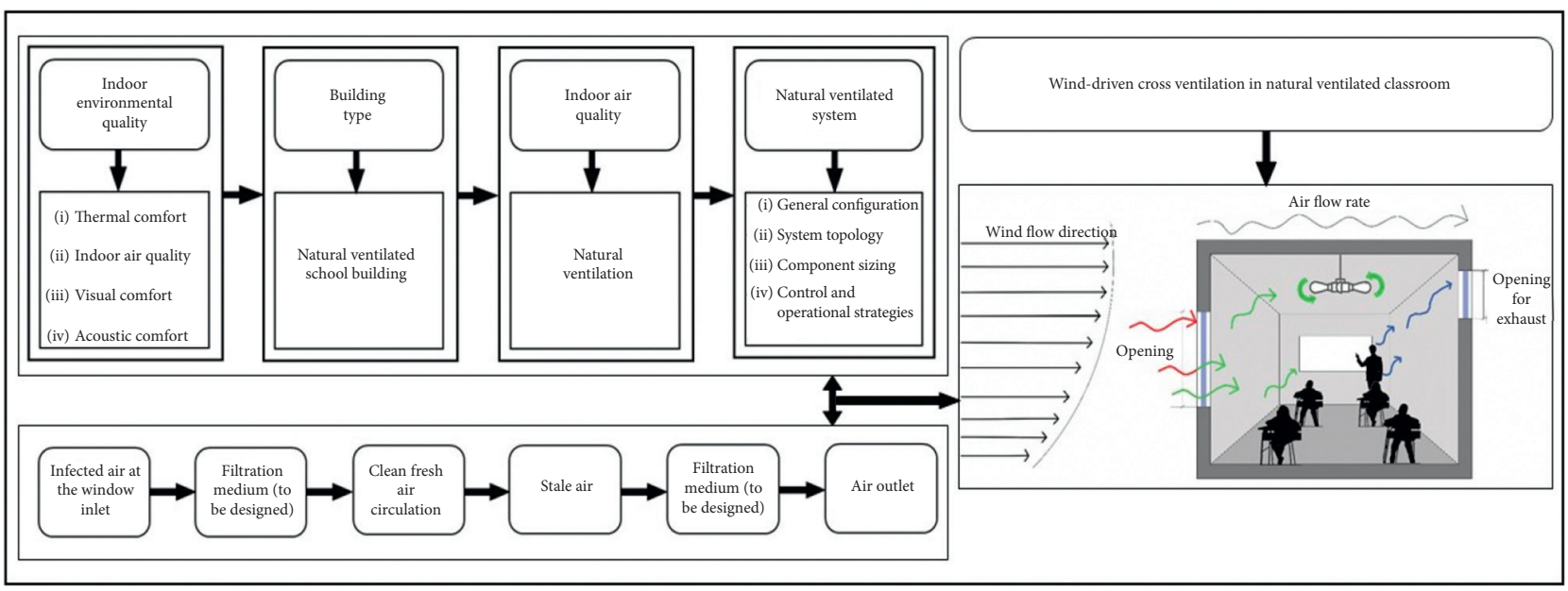

FIGURE 9: Schematic diagram of the proposed filtration system for an NV classroom.

(vi) Different authors adopt different methods for assessing the performance of students; therefore, it is hard to compare as our results and the results of different studies vary significantly. Therefore, there is a need to develop a generic universal methodology on this.

(vii) Less attention is given to acoustic and visual comfort in school buildings; however, a few studies consider the comfort components and found that they are equally important when the focus of the study is on performance and productivity. The standard procedures and well-accepted models of different comfort components are much-needed aspects of school IEQ. Therefore, there is a need to develop a generic methodology/guidelines for acoustic and visual comfort in school buildings.

(viii) No well-accepted code or standard comfort criteria exist for naturally ventilated school buildings. A few studies combine energy efficiency with the IEQ in educational buildings but not particularly in naturally ventilated school buildings. Therefore, there is a need to develop adaptive comfort models/algorithms for NV school buildings.

\subsection{Future Direction}

(i) All the existing schools and other types of buildings need to be retrofitted for improving IEQ and comfort. This requires the development of guidelines and the authors are researching on this.

(ii) For the design and construction of new buildings, a special publication as an Annexure to the National Building Code or a separate document is required. The authors are working on the preparation of the guidelines.

(iii) Similarly, for air-conditioned schools and other buildings, the strategies for air-decontamination are immediately required. Therefore, the authors are researching in this direction to prevent the spread of coronavirus or similar types of viruses that can prevail in the future, in different types of buildings including malls, auditoriums, and offices.

\section{Disclosure}

The work reported in this article forms a part of the AcSIR Ph.D. work of the first author being carried out at CSIRCBRI, Roorkee. The article is published with the permission 
of the Director, CSIR-Central Building Research Institute, Roorkee.

\section{Conflicts of Interest}

The authors declare that there are no conflicts of interest regarding the publication of this paper.

\section{Acknowledgments}

The authors thank Garima Bhanot and Simran Taneja for preparing the figures and drawings in this study. This research was funded by the Department of Science and Technology (DST), New Delhi, India.

\section{References}

[1] N. E. Klepeis, W. C. Nelson, W. R. Ott et al., "The National Human Activity Pattern Survey (NHAPS)," Journal of Exposure Analysis and Environmental Epidemiology, vol. 11, no. 3, pp. 231-252, 2001.

[2] S. Brasche and W. Bischof, "Daily time spent indoors in German homes - baseline data for the assessment of indoor exposure of German occupants," International Journal of Hygiene and Environmental Health, vol. 208, no. 4, pp. 247-253, 2005.

[3] National Building Code of India, Part-4 Fire and Life Safety, Bureau of Indian Standards, Delhi, India, 2016.

[4] V. D. Giuli, O. D. Pos, and M. D. Carli, "Indoor environmental quality and pupil perception in Italian primary schools," Building and Environment, vol. 56, pp. 335-345, 2012.

[5] A. Lizzio, K. Wilson, and R. Simons, "University students' perceptions of the learning environment and academic outcomes: implications for theory and practice," Studies in Higher Education, vol. 27, no. 1, pp. 27-52, 2002.

[6] A. Karapetsis and E. Alexandri, "Indoor environmental quality and its impacts on health - case study: school building," in Proceedings of the EinB2016 - 5th International Conference "Energy in Buildings, Botanique, Greece, November 2016.

[7] M. C. Lee, K. W. Mui, L. T. Wong, W. Y. Chan, E. W. M. Lee, and C. T. Cheung, "Student learning performance and indoor environmental quality (IEQ) in air-conditioned university teaching rooms," Building and Environment, vol. 49, pp. 238-244, 2012.

[8] C. J. Beemer, K. A. S. Yoder, S. J. Schuldt et al., "A brief review on the mental health for select elements of the built environment," Indoor and Built Environment, pp. 1-14, 2019.

[9] S. Choi, D. A. Guerin, H.-Y. Kim et al., "Indoor environmental quality of classrooms and student outcomes: a path analysis approach," Journal of Learning Spaces, vol. 2, no. 2, 2013.

[10] National Institute for Occupational Safety and Health, NIOSH 2013 CDC-Indoor Environmental Quality-NIOSH Workplace Safety and Health, Center for Disease Control and Prevention, Atlanta, GA, USA, 2013.

[11] H. Fromme, D. Twardella, S. Dietrich et al., "Particulate matter in the indoor air of classrooms-exploratory results from Munich and surrounding area," Atmospheric Environment, vol. 41, no. 4, pp. 854-866, 2007.

[12] S. E. Higgins, E. Hall, K. Wall et al., The Impact of School Environments: A Literature Review, The Centre for Learning and Teaching-School Education, University of Newcastle, Callaghan, Australia, 2005.

[13] S. M. Kennedy, M. Hodgson, and L. D. Edgettet, "Subjective assessment of listening environments in university classrooms: perceptions of students," Journal of the Acoustical Society of America, vol. 119, no. 1, pp. 299-309, 2005.

[14] G. Newsham, J. Brand, C. Donnelly, J. Veitch, M. Aries, and K. Charles, "Linking indoor environment conditions to job satisfaction: a field study," Building Research and Information, vol. 37, no. 2, pp. 129-147, 2009.

[15] P. Temple and O. Filippakou, Learning Spaces for the 21st Century: A Review of the Literature, Thesis, University of London, London, UK, 2007.

[16] J. C. Vischer, "The effects of the physical environment on job performance: towards a theoretical model of workspace stress," Stress and Health, vol. 23, no. 3, pp. 175-184, 2007.

[17] J. R. Carlopio, "Construct validitb by of a physical work environment satisfaction questionnaire," Journal of Occupational Health Psychology, vol. 1, no. 3, pp. 330-344, 1996.

[18] R. de Dear, J. Kim, C. Candido, and M. Deuble, "Adaptive thermal comfort in Australian school classrooms," Building Research \& Information, vol. 43, no. 3, pp. 383-398, 2015.

[19] W. J. Fisk, "Health and productivity gains from better indoor environments and their relationship with building energy efficiency," Annual Review of Energy and the Environment, vol. 25, no. 1, pp. 537-566, 2000.

[20] M. J. Mendell and G. A. Heath, "Do indoor pollutants and thermal conditions in schools influence student performance? A critical review of the literature," Indoor Air, vol. 15, no. 1, pp. 27-52, 2005.

[21] D. P. Wyon and Wargocki, "How indoor environment affects performance,” Ashrae Journal, vol. 55, no. 3, pp. 46-52, 2013.

[22] J. M. Seltzer, "Building-related illnesses," Journal of Allergy and Clinical Immunology, vol. 94, no. 2, pp. 351-361, 1994.

[23] P. S. Burge, "Sick building syndrome," Occupational and Environmental Medicine, vol. 61, no. 2, pp. 185-190, 2004.

[24] S. Joshi, "The sick building syndrome," Indian Journal of Occupational and Environmental Medicine, vol. 12, no. 2, pp. 61-64, 2008.

[25] P. Wargocki, D. P. Wyon, Y. K. Baik, G. Clausen, and P. O. Fanger, "Perceived air quality, sick building syndrome (SBS) symptoms and productivity in an office with two different pollution loads," Indoor Air, vol. 9, no. 3, pp. 165-179, 1999.

[26] T. Catalina and V. Iordache, "IEQ assessment on schools in the design stage," Building and Environment, vol. 49, pp. 129-140, 2012.

[27] Government of India, National Education Policy-2020, Ministry of Human Resource Development, New Delhi, India, 2020.

[28] A. Jindal, "Thermal comfort study in naturally ventilated school classrooms in composite climate of India," Building and Environment, vol. 142, pp. 34-46, 2018.

[29] Bureau of Indian Standards, Handbook on Functional Requirements of Buildings (SP-41), Bureau of Indian Standards, New Delhi, India, 1987.

[30] National Building Code of India, Bureau of Indian Standards, National Building Code of India, New Delhi, India, 2016.

[31] Indian Society of Heating, Refrigerating and Air Conditioning Engineers, Indoor Environmental Quality Standard (ISHRAE-10001), Indian Society of Heating, New Delhi, India, 2019. 
[32] ASHRAE Standard 55-2010, Thermal Environmental Conditions for Human Occupancy, ASHRAE Standard 55-2010, Atlanta, GA, USA, 2010.

[33] ISO, ISO7730:2005, ISO, Geneva, Switzerland, 2005.

[34] European Standards, Energy Performance of Buildings-Ventilation for Buildings-Part 1: Indoor Environmental Input Parameters for Design and Assessment of Energy Performance of Buildings Addressing Indoor Air Quality (EN16798-1), Comité Euroéen de Normalisa, Brussels, Belgium, 2019.

[35] European Standard, Light and Lighting-Basic Terms and Criteria for Specifying Lighting Requirements (EN12665), Comité Européen de Normalisation, Brussels, Belgium, 2002.

[36] ISO, CIE, Lighting of Indoor Work Places, ISO, Geneva, Switzerland, 2002.

[37] American Society of Heating, Refrigerating and Air-Conditioning Engineers, Ventilation for Acceptable Indoor Air Quality (ASHRAE62.1), American Society of Heating, Atlanta, GA, USA, 2013.

[38] American National Standards Institute, American National Standard Acoustical Performance Criteria, Design Requirements, and Guidelines for Schools, Part 1: Permanent Schools (ANSI-ASAS12.60, Part 1), Acoustical Society of America, Melville, NY, USA, 2010.

[39] M. Schneider, Do School Facilities Affect Academic Outcomes, 2002.

[40] E. A. Hanushek and S. G. Rivkin, "Harming the best: how schools affect the black-white achievement gap," Journal of Policy Analysis and Management, vol. 28, no. 3, pp. 366-393, 2009.

[41] R. Becker, I. Goldberger, and M. Paciuk, "Improving energy performance of school buildings while ensuring indoor air quality ventilation," Building and Environment, vol. 42, no. 9, pp. 3261-3276, 2007.

[42] W. J. Fisk, Q. Lei-Gomez, and M. J. Mendell, "Meta-analyses of the associations of respiratory health effects with dampness and mold in homes," Indoor Air, vol. 17, no. 4, pp. 284-296, 2007.

[43] M. S. Jaakkola, R. Quansah, T. T. Hugg, S. A. M. Heikkinen, and J. J. K. Jaakkola, "Association of indoor dampness and molds with rhinitis risk: a systematic review and metaanalysis," Journal of Allergy and Clinical Immunology, vol. 132, no. 5, pp. 1099-1110, 2013.

[44] G. R. Passarelli, "Sick building syndrome: an overview to raise awareness," Journal of Building Appraisal, vol. 5, no. 1, pp. 55-66, 2009.

[45] D. Thivel, A. Tremblay, P. M. Genin et al., "Physical activity, inactivity, and sedentary behaviors: definitions and implications in occupational health," Front Public Health, vol. 6, no. $288,2018$.

[46] A. Jindal, "Investigation and analysis of thermal comfort in naturally ventilated secondary school classrooms in the composite climate of India," Architectural Science Review, vol. 62, no. 6, pp. 466-484, 2019.

[47] M. A. Mujeebu, Introductory Chapter: Indoor Environmental Quality, pp. 1-13, IntechOpen, London, UK, 2019.

[48] C. Kielb, S. Lin, N. Muscatiello, W. Hord, J. Rogers-Harrington, and J. Healy, "Building-related health symptoms and classroom indoor air quality: a survey of school teachers in New York State," Indoor Air, vol. 25, no. 4, pp. 371-380, 2015.

[49] N. E. Ebbehoj, H. W. Meyer, H. Wurtz et al., "Molds in floor dust, building-related symptoms, and lung function among male and female schoolteachers," Indoor Air, vol. 15, no. 10, pp. 7-16, 2005.
[50] J. Ervasti, M. Kivimaki, I. Kawachi et al., "School environment as predictor of teacher sick leave: data-linked prospective cohort study," BMC Public Health, vol. 12, no. 770, pp. 1-8, 2012.

[51] M. Schneider, "Linking school facility conditions to teacher satisfaction and success," ERIC publication reports-research, pp. 1-5, ERIC, Washington, DC, USA, 2003.

[52] A. Kumar, A. Singh, M. K. Singh, P. Mahanta, and S. C. Mukhopadhyay, "Sensing technologies for monitoring intelligent buildings: a review," IEEE Sensors Journal, vol. 18, no. 12, pp. 4847-4860, 2018.

[53] R. Gupta, M. Gregg, S. Manu et al., "Customized performance evaluation approach for Indian green buildings," Building Research \& Information, vol. 47, no. 1, pp. 56-74, 2019.

[54] J. Langevin, J. Wen, and P. L. Gurian, "Modeling thermal comfort holistically: bayesian estimation of thermal sensation, acceptability, and preference distributions for office building occupants," Building and Environment, vol. 69, pp. 206-226, 2013.

[55] M. C. Peel, B. L. Finlayson, and T. A. McMahon, "Updated world map of the Köppen-Geiger climate classification," Hydrology and Earth System Sciences Discussions, European Geosciences Union, vol. 11, no. 5, pp. 1633-1644, 2007.

[56] H.-H. Liang, C.-P. Chen, W.-M. Shih, S.-C. Lo, and H.-Y. Liao, "Satisfaction of occupants toward indoor environment quality of certified green office buildings in Taiwan," Building and Environment, vol. 72, pp. 232-242, 2014.

[57] R. J. de Dear, T. Akimoto, E. A. Arens et al., "Progress in thermal comfort research over the last twenty years," Indoor Air, vol. 23, no. 6, pp. 442-461, 2013.

[58] G. A. Heath and M. J. Mendell, "Do indoor environments in schools influence student performance? A critical review of the literature," Indoor Air Journal, vol. 15, pp. 27-32, 2005.

[59] Z. S. Zomorodian, M. Tahsildoost, and M. Hafezi, "Thermal comfort in educational buildings: a review article," Renewable and Sustainable Energy Reviews, vol. 59, pp. 895-906, 2016.

[60] M. Pinto, R. Almeida, P. Pinho et al., "Experimental assessment of IAQ improvement in naturally ventilated educational buildings," in Proceedings of the 40th IAHS World Congress on Housing Sustainable Housing Construction, pp. 1-10, Funchal, Portugal, December 2014.

[61] P. Wargocki and D. P. Wyon, "Effects of HVAC on student performance," ASHRAE Journal, 2006.

[62] J. A. Bargh and I. Shalev, "The substitutability of physical and social warmth in daily life," American Psychological Association Journal EMOTION, vol. 12, pp. 154-162, 2012.

[63] L. Schellen, M. Loomans, M. de Wit, and W. van Marken Lichtenbelt, "The influence of different cooling techniques and gender on thermal perception," Building Research and Information, vol. 41, no. 3, pp. 330341, 2013.

[64] M. R. Sharma and S. Ali, "Tropical summer index-a study of thermal comfort of Indian subjects," Building and Environment, vol. 21, no. 1, pp. 11-24, 1986.

[65] A. P. Gagge, A. P. Fobelets, and L. G. Berglund, "A standard predictive Index of human response to thermal environment," Transactions/American Society of Heating, Refrigerating and Air-Conditioning Engineers, vol. 92, no. 2B, pp. 709-731, 1986.

[66] J. V. Hoof, "Forty years of Fanger's model of thermal comfort: comfort for all?" Indoor Air, vol. 18, no. 3, pp. 182-201, 2008. 
[67] S. Manu, Y. Shukla, R. Rawal, L. E. Thomas, and R. de Dear, "Field studies of thermal comfort across multiple climate zones for the subcontinent: India Model for Adaptive Comfort (IMAC)," Building and Environment, vol. 98, pp. 55-70, 2016.

[68] European Standards, Indoor Environmental Input Parameters for Design and Assessment of Energy Performance of Buildings Addressing Indoor Air Quality, Thermal Environment, Lighting and Acoustics (EN 15251), Comité Européen de Normalisation, Brussels, Belgium, 2006.

[69] B. Bronsema et al., Performance Criteria of Buildings for Health and comfort (Report of International Society of Indoor Air Quality and Climate, International Council for Research and Innovation in Building and Construction (CIB) Task Group TG 42, CIB Number 192), The Netherlands, 2004.

[70] O. Seppanen and W. Fisk, "Some quantitative relations between indoor environmental quality and work performance or health," HVAC\&R Research, vol. 12, no. 4, pp. 957-973, 2006.

[71] S. Barbhuiya and S. Barbhuiya, "Thermal comfort and energy consumption in a UK educational building," Building and Environment, vol. 68, pp. 1-11, 2013.

[72] J. Nakano, S.-i. Tanabe, and K.-i. Kimura, "Differences in perception of indoor environment between Japanese and non-Japanese workers," Energy and Buildings, vol. 34, no. 6, pp. 615-621, 2002.

[73] A. Melikov, G. Pitchurov, K. Naydenov, and G. Langkilde, "Field study on occupant comfort and the office thermal environment in rooms with displacement ventilation," Indoor Air, vol. 15, no. 3, pp. 205-214, 2005.

[74] R. V. Andersen, J. Toftum, K. K. Andersen, and B. W. Olesen, "Survey of occupant behaviour and control of indoor environment in Danish dwellings," Energy and Buildings, vol. 41, no. 1, pp. 11-16, 2009.

[75] M. K. Singh, S. Kumar, R. Ooka, H. B. Rijal, G. Gupta, and A. Kumar, "Status of thermal comfort in naturally ventilated classrooms during the summer season in the composite climate of India," Building and Environment, vol. 128, pp. 287-304, 2018.

[76] L. Noda, A. V. P. Lima, J. F. Souza et al., "Thermal and visual comfort of schoolchildren in air-conditioned classrooms in hot and humid climates," vol. 182, pp. 1-12, 2020.

[77] M. K. Singh, R. Ooka, H. B. Rijal, S. Kumar, A. Kumar, and S. Mahapatra, "Progress in thermal comfort studies in classrooms over last 50 years and way forward," Energy and Buildings, vol. 188-189, pp. 149-174, 2019.

[78] A. Szczurek, M. Maciejewska, and M. Wyłomańska, "Method to characterize collective impact of factors on indoor air," Physica A: Statistical Mechanics and Its Applications, vol. 420, pp. 190-199, 2015.

[79] S. N. Kamaruzzaman, C. O. Egbu, E. M. A. Zawawi et al., "The effect of indoor environmental quality on occupants' perception of performance: a case study of refurbished historic buildings in Malaysia," Energy and Buildings, vol. 43, no. 2-3, pp. 407-413, 2011.

[80] L. D. Stetzenbach, M. P. Buttner, and P. Cruz, "Detection and enumeration of airborne biocontaminants," Current Opinion in Biotechnology, vol. 15, no. 3, pp. 170-174, 2004.

[81] R. J. Heinsohn and J. M. Cimbala, Indoor Air Quality Engineering: Environmental Health and Control of Indoor Pollutants, Marcel Dekker, New York; Basel, NY, USA, 2003.

[82] S. R. Tortolero, L. K. Bartholomew, S. Tyrrell et al., "Environmental allergens and irritants in schools: a focus on asthma," Journal of School Health, vol. 72, no. 1, pp. 33-38, 2002.

[83] K. Foarde and M. Berry, "Comparison of biocontaminant levels associated with hard vs. carpet floors in nonproblem schools: results of a year long study," Journal of Exposure Science and Environmental Epidemiology, vol. 14, no. S1, pp. S41-S48, 2004.

[84] C. C. Bullock, "The relationship school building conditions and student achievement at the middle school level in the commonwealth of Virginia," Dissertation report, Virginia Tech, Blacksburg, VA, USA, 2007.

[85] D. P. Wyon, "The effects of indoor air quality on performance and productivity," Indoor Air, vol. 14, pp. 92-101, 2004.

[86] H. Lorsch and O. Abdou, "The impact of the building indoor environment on occupant productivity-Part 1-Recent studies, measures and costs. Part 2-Effects of temperature. Part 3-Effects of indoor air quality," InFuel and Energy Abstracts, 1995.

[87] Bureau of Indian Standards, Recommendations for Basic Requirements of School Buildings (IS-8827), Bureau of Indian Standards, New Delhi, India, 1978.

[88] European Standard, Technical report (CR-1752-1998), Comité Européen de Normalisation, Brussels, Belgium, 1998.

[89] B. W. Olesen, "International standards for the indoor environment," Indoor Air, vol. 14, no. s7, pp. 18-26, 2004.

[90] M. Schweiker, S. Brasche, W. Bischof, M. Hawighorst, and A. Wagner, "Explaining the individual processes leading to adaptive comfort: exploring physiological, behavioural and psychological reactions to thermal stimuli," Journal of Building Physics, vol. 36, no. 4, pp. 438-463, 2013.

[91] P. Barrett, F. Davies, Y. Zhang, and L. Barrett, "The impact of classroom design on pupils' learning: final results of a holistic, multi-level analysis," Building and Environment, vol. 89, pp. 118-133, 2015.

[92] L. Heschong, R. L. Wright, and S. Okura, "Daylighting impacts on human performance in school," Journal of the Illuminating Engineering Society, vol. 31, no. 2, pp. 101-114, 2002.

[93] J. M. Daisey, W. J. Angell, and M. G. Apte, "Indoor air quality, ventilation and health symptoms in schools: an analysis of existing information," Indoor Air, vol. 13, no. 1, pp. 53-64, 2003.

[94] F. Haghighat and G. Donnini, "Impact of psycho-social factors on perception of the indoor air environment studies in 12 office buildings," Building and Environment, vol. 34, no. 4, pp. 479-503, 1999.

[95] W. Yu, L. Wang, Q. Wang et al., "Design selection and evaluation method of PM2.5 filters for fresh air systems," Journal of Building Engineering, vol. 27, 2020.

[96] O. A. Seppänen, W. J. Fisk, and M. J. Mendell, “Association of ventilation rates and $\mathrm{CO} 2$ concentrations with health andOther responses in commercial and institutional buildings," Indoor Air, vol. 9, no. 4, pp. 226-252, 1999.

[97] L. Kajtár, L. Herczeg, E. Láng et al., "Influence of carbondioxide pollutant on human well-being and work intensity," in Proceedings of Healthy Buildings Conference HB 2006Healthy Buildings: Creating a Healthy Indoor Environment for People, pp. 85-90, Lisboa, Portugal, August 2006.

[98] UK Building Bulletin 101, Ventilation of School Buildings (BB 101), UK, 2005.

[99] H. Shaughnessy, U. D. J. Moschandreas, and R. J. Shaughnessy, "Association between substandard classroom ventilation rates and students' academic achievement," Indoor Air, vol. 21, no. 2, pp. 121-131, 2010. 
[100] C. Croome, D. J. Clements, N. Kocchar et al., "Ventilation rates in schools," Building and Environment, vol. 43, no. 3, pp. 362-367, 2008.

[101] D. G. Shendell, A. M. Winer, R. Weker, and S. D. Colome, "Evidence of inadequate ventilation in portable classrooms: results of a pilot study in Los Angeles County," Indoor Air, vol. 14, no. 3, pp. 154-158, 2004.

[102] C. C. Araya, C. Shrubsole, H. Altamirano et al., "Should schools located in polluted areas be naturally ventilated? A case study from Chile," in Proceeding of 4th Masters Conference: People and Buildings, London, UK, September 2014.

[103] Z. Peng, W. Deng, and R. Tenorio, "An integrated lowenergy ventilation system to improve indoor environment performance of school buildings in the cold climate zone of China," Building and Environment, vol. 182, 2020.

[104] J. A. Leech, W. C. Nelson, R. T. Burnett, S. Aaron, and M. E. Raizenne, "It's about time: a comparison of Canadian and American time-activity patterns," Journal of Exposure Science and Environmental Epidemiology, vol. 12, no. 6, pp. 427-432, 2002.

[105] D. K. Serghides, C. K. Chatzinikola, and M. C. Katafygiotou, "Comparative studies of the occupants' behaviour in a university building during winter and summer time," International Journal of Sustainable Energy, vol. 34, no. 8, pp. 528-551, 2014.

[106] J. A. Veitch, "Psychological processes influencing lighting quality," Journal of the Illuminating Engineering Society, vol. 30, no. 1, pp. 124-140, 2013.

[107] L. Edwards and P. Torcellini, Literature Review of the Effects of Natural Light on Building Occupants, National Renewable Energy Lab., Golden, CO. USA, 2002.

[108] M. S. Alrubaih, M. F. M. Zain, M. A. Alghoul, N. L. N. Ibrahim, M. A. Shameri, and O. Elayeb, "Research and development on aspects of daylighting fundamentals," Renewable and Sustainable Energy Reviews, vol. 21, pp. 494-505, 2013.

[109] National Building Codes of India, NBC Part-4 Building Types inIndia, Bureau of Indian Standards, New Delhi, India, 2005.

[110] Indian Standards, Guide for Daylighting of Buildings (IS2440), Bureau of Indian Standards, New Delhi, India, 1975.

[111] Indian Standards, Code of Practice for Daylighting of Educational Buildings (IS-7942), Bureau of Indian Standards, New Delhi, India, 1976.

[112] UK Building Bulletin 90, Lighting Design for Schools (BB 90), UK, 1999.

[113] K. Jain, A. Kumar, and A. Kumar, App for Integrating Daylight with Artificial Lighting for Improving Building Energy Efficiency of Residential and Commercial Building during Daytime in All Sky Conditions of United Kingdom (ROC-SW-12453/2019), Extracts from The Register of Copyrights, Copyright Office GOI, 2019.

[114] O. A. Abdou, "Effects of luminous environment on worker productivity in building spaces," Journal of Architectural Engineering, vol. 3, no. 3, pp. 124-132, 1997.

[115] J. K. Rice, Teacher Quality: Understanding the Effectiveness of Teacher Attributes, 2003.

[116] N. Hanford and M. Figueiro, "Light therapy and Alzheimer's disease and related dementia: past, present, and future," Journal of Alzheimer's Disease, vol. 33, no. 4, pp. 913-922, 2013.

[117] G. O. Ocvirk, Art Fundamental: Theory and Practice, McGraw-Hill, New York, NY, USA, 2009.

[118] M. B. C. Aries, J. A. Veitch, and G. R. Newsham, "Windows, view, and office characteristics predict physical and psychological discomfort," Journal of Environmental Psychology, vol. 30, no. 4, pp. 533-541, 2010.

[119] M. John and E. H. Timothy, "Illuminating the classroom environment," School Planning and Management, vol. 44, no. 2, pp. 34-45, 2005.

[120] F. Nicol, M. Wilson, and C. Chiancarella, "Using field measurements of desktop illuminance in European offices to investigate its dependence on outdoor conditions and its effect on occupant satisfaction, and the use of lights and blinds," Energy and Buildings, vol. 38, no. 7, pp. 802-813, 2006.

[121] H. Zhang, E. Arens, D. Kim, E. Buchberger, F. Bauman, and C. Huizenga, "Comfort, perceived air quality, and work performance in a low-power task-ambient conditioning system," Building and Environment, vol. 45, no. 1, pp. 29-39, 2010.

[122] M. Bessoudo, A. Tzempelikos, A. K. Athienitis, and R. Zmeureanu, "Indoor thermal environmental conditions near glazed facades with shading devices - Part I: experiments and building thermal model," Building and Environment, vol. 45, no. 11, pp. 2506-2516, 2010.

[123] P. Barrett and Y. Zhang, "Teachers' views on the designs of their primary schools," Intelligent Buildings International, vol. 4, no. 2, pp. 89-110, 2012.

[124] A. Kumar, A. Kumar, and K. Jain, “Apps for Integrating Daylight with Artificial Lighting for Improving Building Energy Efficiency during Daytime in All Climatesof India," Extracts from the Register of Copyrights, Copyright Office GOI, ROC-SW-12111/2019, 2019.

[125] E. Ghisi and J. A. Tinker, "An ideal window area concept for energy efficient integration of daylight and artificial light in buildings," Building and Environment, vol. 40, no. 1, pp. 51-61, 2005.

[126] G. W. Evans, "Child development and the physical environment," Annual Review of Psychology, vol. 57, no. 1, pp. 423-451, 2006.

[127] W. E. Hathaway, "Effects of school lighting on physical development and school performance," The Journal of Educational Research, vol. 88, no. 4, pp. 228-242, 2010.

[128] A. Lewy, T. Wehr, F. Goodwin, D. Newsome, and S. Markey, "Light suppresses melatonin secretion in humans," Science, vol. 210, no. 4475, pp. 1267-1269, 1980.

[129] N. R. Kapoor and J. P. Tegar, "Human comfort indicators pertaining to indoor environmental quality parameters of residential buildings in Bhopal," International Research Journal of Engineering and Technology, vol. 5, pp. 2395-0056, 2018.

[130] X. Li, Y. Wei, J. Zhang, and P. Jin, "Design and analysis of an active daylight harvesting system for building," Renewable Energy, vol. 139, pp. 670-678, 2019.

[131] K. D. Kryter, "Non-auditory effects of environmental noise," Environmental Noise, pp. 389-398, 1986.

[132] K. D. Kryter, The Effects of Noise on Man, Elsevier, Armsterdam, The Netherlands, 2013.

[133] Y. Osada, “An overview of health effects on noise," Journal of Sound and Vibration, vol. 127, no. 3, pp. 407-410, 1988.

[134] T. Z. Chang, R. Mehta, S. J. Chen, P. Polsa, and J. Mazur, "The effects of market orientation on effectiveness and efficiency: the case of automotive distribution channels in Finland and Poland," Journal of Services Marketing, vol. 13, no. 4/5, pp. 407-418, 1999.

[135] M. A. Wallenius, "The interaction of noise stress and personal project stress on subjective health," Journal of Environmental Psychology, vol. 24, no. 2, pp. 167-177, 2004. 
[136] M. Kohlhuber, A. Mielck, S. K. Weiland, and G. Bolte, "Social inequality in perceived environmental exposures in relation to housing conditions in Germany," Environmental Research, vol. 101, no. 2, pp. 246-255, 2006.

[137] U. Landstrom, E. Akerlund, A. Kjellberg, and M. Tesarz, "Exposure levels, tonal components, and noise annoyance in working environments," Environment International, vol. 21, no. 3, pp. 265-275, 1995.

[138] I. Rabiyanti, I. Rahmaniar, and J. C. P. Putra, "Effect of acoustic and thermal comfort to support learning process in a university," Procedia Engineering, vol. 170, pp. 280-285, 2017.

[139] UK Building Bulletin 93, Acoustic Design of Schools: Performance Standard, 2015.

[140] G. Tiesler, R. Machner, and H. Brokmann, "Classroom acoustics and impact on health and social behaviour," Energy Procedia, vol. 78, pp. 3108-3113, 2015.

[141] L. M. Rantala, S. Hakala, S. Holmqvist, and E. Sala, "Classroom noise and teachers' voice production," Journal of Speech, Language, and Hearing Research, vol. 58, no. 5, pp. 1397-1406, 2015.

[142] M. R. Serra and E. C. Biassoni, "Urban noise and classroom acoustical conditions in the teaching-learning process," International Journal of Environmental Studies, vol. 56, no. 1, pp. 41-59, 1998.

[143] P. M. Bluyssen, M. Aries, and P. V. Dommelen, "Comfort of workers in office buildings: the European HOPE project," Building and Environment, vol. 46, no. 1, pp. 280-288, 2011.

[144] P. M. Bluyssen, S. Janssen, L. H. van den Brink et al., "Assessment of wellbeing in an indoor office environment," Building and Environment, vol. 46, no. 12, pp. 2632-2640, 2011.

[145] UNESCO, Framework for Reopening Schools, UNESCO, Paris, France, 2020.

[146] GOI, Guidelines on Disinfection of Common Public Places Including Offices, GOI, New Delhi, 2020.

[147] ISHRAE, COVID-19 Guidance Document for Air Conditioning and Ventilation, ISHRAE, Chennai, India, 2020.

[148] Z. T. Ai and A. K. Melikov, "Airborne spread of expiratory droplet nuclei between the occupants of indoor environments: a review," Indoor Air, vol. 28, no. 4, pp. 500-524, 2018.

[149] V. Mathai, A. Das, J. A. Bailey et al., "Airflows inside passenger cars and implications for airborne disease transmission," Science Advances, vol. 7, no. 1, Article ID eabe0166, 2020.

[150] S. C. Moharir, T. S. Chandra, A. Goel et al., Detection of SARS-CoV-2 in the Air from Hospitals and Closed Rooms Occupied by COVID-19 Patients, Medrxiv Preprint, 2021.

[151] L. Liu, Y. Li, P. V. Nielsen, J. Wei, and R. L. Jensen, "Shortrange airborne transmission of expiratory droplets between two people," Indoor Air, vol. 27, no. 2, pp. 452-462, 2017. 